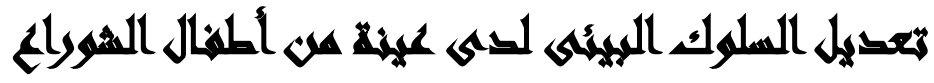

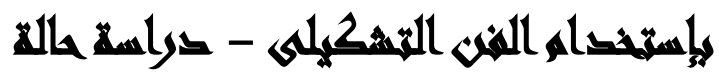

\author{
نهلة صلاح على(')- الثيماء بلر عامر (1) \\ ( ) معهد الدراسات والبحوث البيئية، جامعة عين شمس عل(1)
}

\section{antionall}

هدف البحث الحالى الى محاولة تعديل السلوك البيئى لدى عينة من أطفال الثوراع

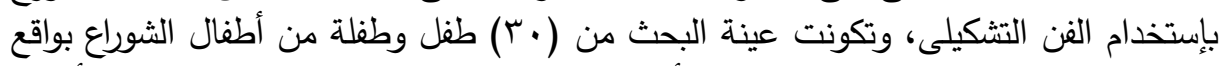

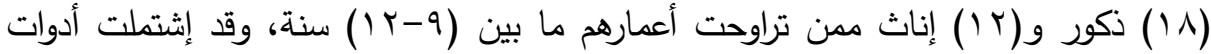

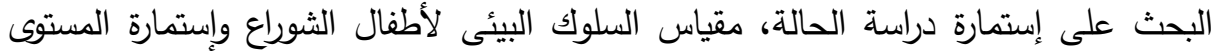
الاجتماعى الاقتصادى (إعداد الباحثتان).

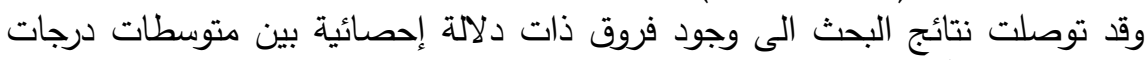

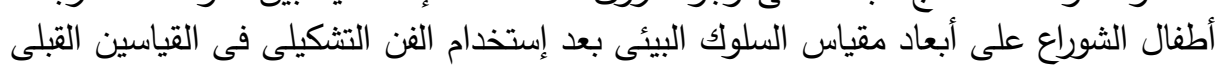

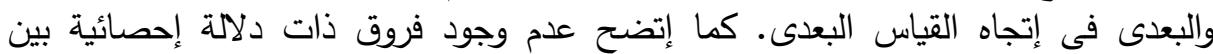

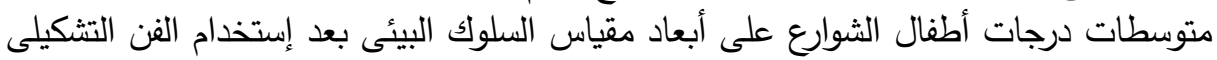

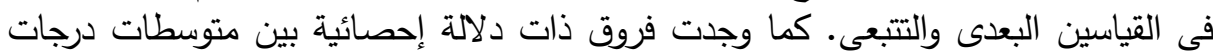

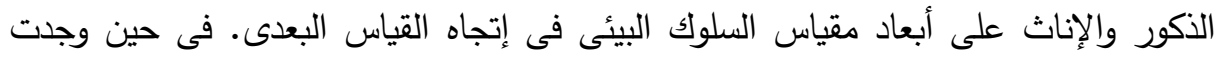

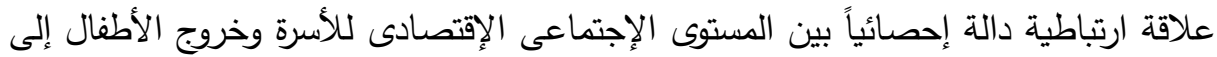

الثارع. وأوصى البحث بضرورة توفير نظام إجتماعى يهتم بتفعيل آلية لرصد أطفال الثوارع

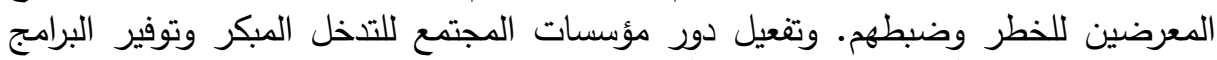

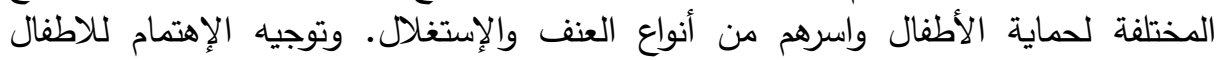

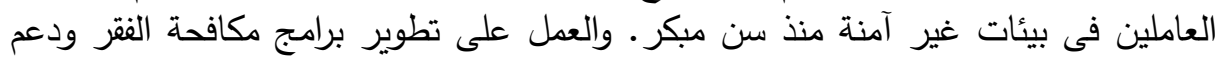

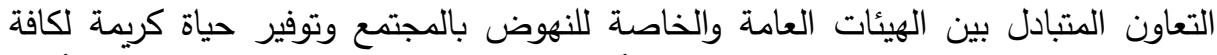

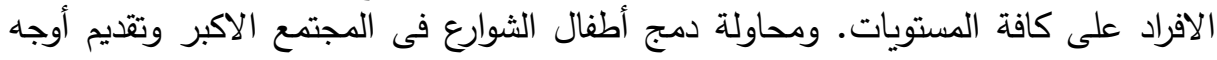
الرعاية المختلفة لهم وتحويلهم لطاقة إيجابية تقيد المجتمع لا تضره.

$$
\begin{aligned}
& \text { المجلد التاسع والأربعون، العدد السابع، الجزء الخامس، يوليو . r. }
\end{aligned}
$$

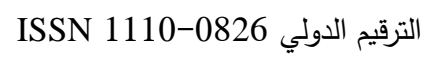




\section{insoll}

لقد أصبحت قضايا الطفولة محل إهتمام وبحث كبيرين على المستوى المحلى والعالمى، ووفقا للتغيرات الحالية التى أصبح يشهدها المجتمع فى مختلف المجالات فقد ساهم ذلك فى إلى ظهور العديد من المشكلات التى تهدد سلامة وأمن وتقدم البلاد، والتى من أهمها مشكلة "أطفال الشوارع".

حيث أن ظاهرة الأطفال الذين يعيشون على مسئوليتهم ليست جديدة، فقد شهد الماضى أطفال الشوارع بشكل عابر من نافذة التاريخ فى مناسبات عديدة، مثل الاضطرابات الاجتماعية أو التحول السربع، ولكن ما يلفت النظر تثابه الفئات الحديثة والقديمة وآليات بناء هذه الفئات واحدة تقرببا فى أى زمان ومكان.

فقد أصبحت تلك المشكلة آخذه فى الزيادة حتى أنها أصبحت تشكل كابوساً مزعجاً ليس فقط فى بلدان العالم الثالث وانما أيضا فى بعض الدول الصناعية المتقدمة وذلك لما لها من لهن

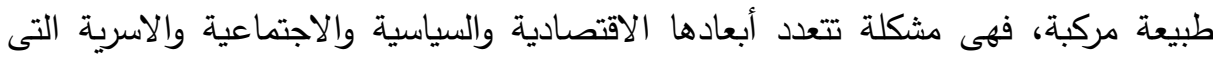

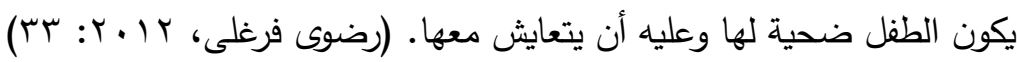

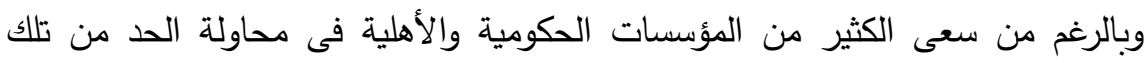

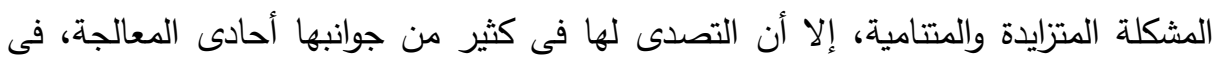

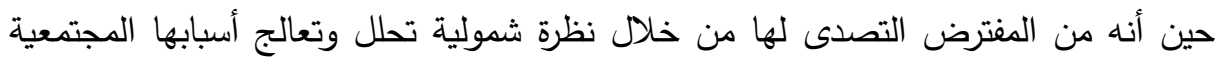

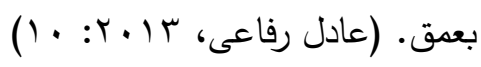

وهذا بالطبع لا يمكن أن يتحقق دون تضافر كل الجهود فى المجتمع لمواجهة تلك

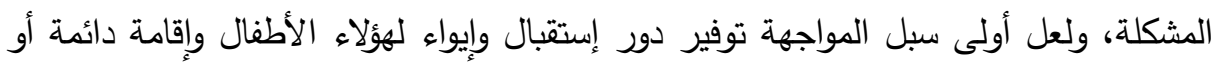

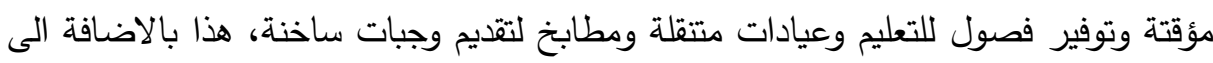
الرعاية الاجتماعية والنفسية من جانب الاخصائيين الاجتماعيين للتعرف على مشاكل وعلى هؤلاء

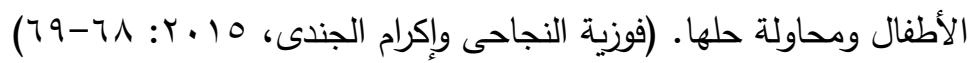


وفى إطار ذلك يمكن التدخل من خلال البرامج المختلفة التدريبية والارشادية والعلاجية

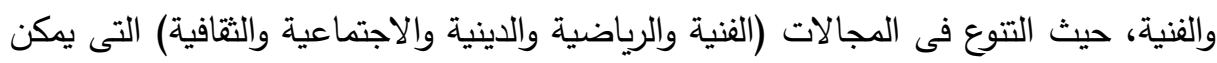
ان تجذب الأطفال أولا ثم تؤتى ثمارها بالنفع عليهم، فهم فى حاجة الى من يقدم لهم يد العون ليحيوا حياه كريمة.

وكجزء من العناية باطفال الثوارع يمكن إستخدام الوسائط الفنية المتعددة لتدريب هؤلاء الاطفال واستثمار طاقاهتم وقدراتهم حتى وإن كانت محدودة فى توجيه سلوكهم البيئى. وحيث أن إتجاهات الاطفال الايجابية نحو بيئتهم ترتبط بمدى إثباع هذه البيئة لحاجاتهم

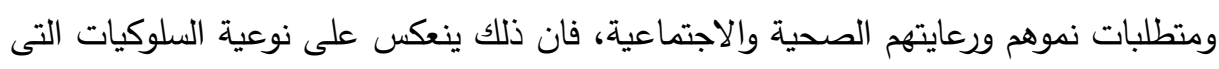
تصدر عنهم نحو هذه البيئة. وهنا يمكن التدخل من خلال الفن التشكيلى والذى يعد من أهم الوسائط التى لها جاذبية كبيرة بما يتضمنه من ادوات وخامات ومجالات متتوعة فى تعديل السلوك البيئى لاى اطفى الطفال

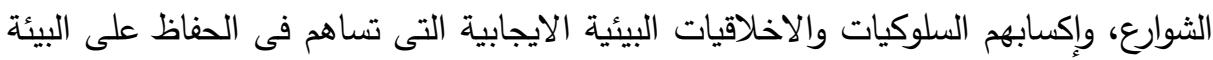
وحمايتها من التعدى.

\section{Aadilating}

تُعد مشكلة أطفال الثوارع من أثد الظواهر الاجتماعية المعبرة عن الطفولة المنتهكة

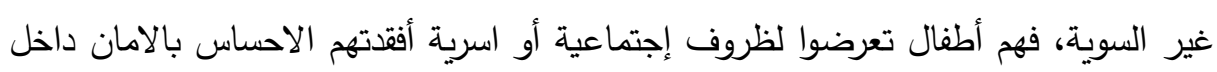

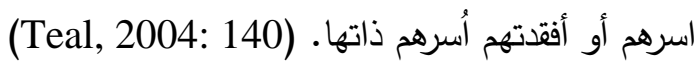
فقد تفاقمت مشكلة أطفال الشوارع في مصر تفاقًَا ملحوظًا في السنوات الأخيرة، والتي التي

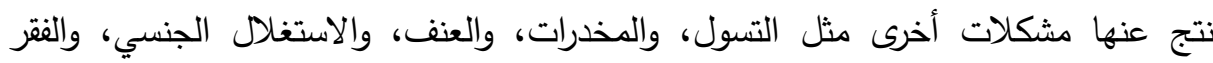

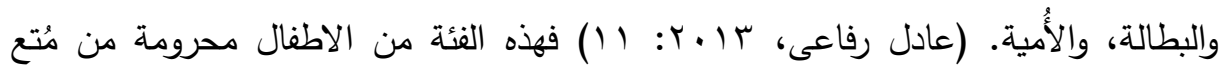

$$
\begin{aligned}
& \text { المجلد التاسع والأربعون، العدد السابع، الجزء الخامس، يوليو · r. }
\end{aligned}
$$

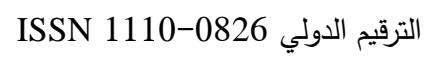


ومباهج مرحلة الطفولة حتى أن الكثير منهم عرضه للموت المبكر بسبب الفقر والمرض أو

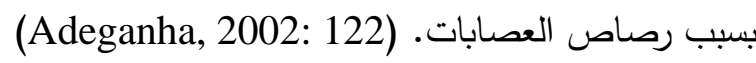

فلا يكاد يخلو شارعاً واحداً من هؤلاء الاطفال بشكل أو بآخر إما بالتسول أو البيع فى التى

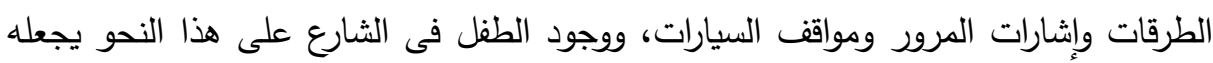

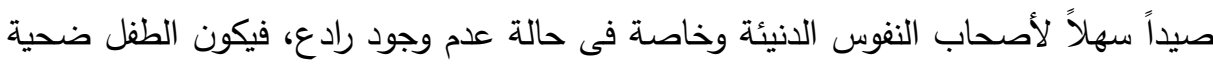

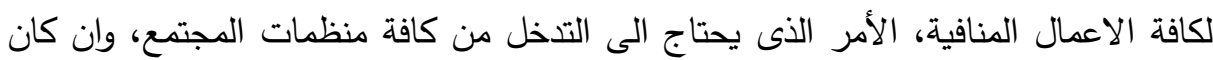

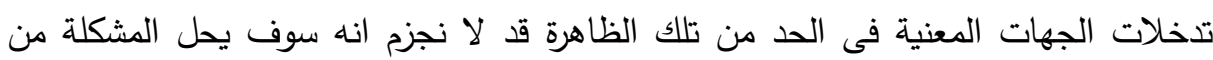

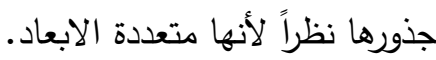
ولعل الأمر يرتبط بشكل كبير بأسر هؤلاء الأطفال وما يلقاه الطفل داخل الاسرة من الأبعاد

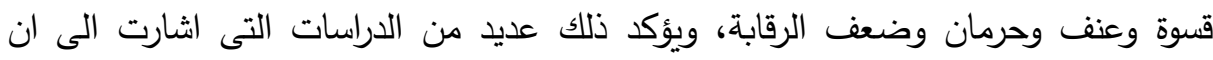
التنكك الاسرى من العوامل الاساسية بل والاولى فى مشكلة اطفال الثوارع.

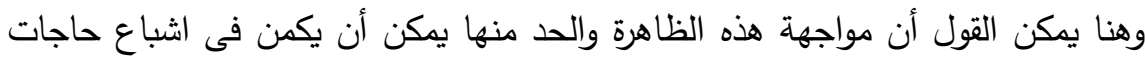
هؤلاء الاطفال وتقديم اوجه الرعاية المختلفة لهم، وذلك من خلال البكال البرامج والوسائط الفنية التى التى

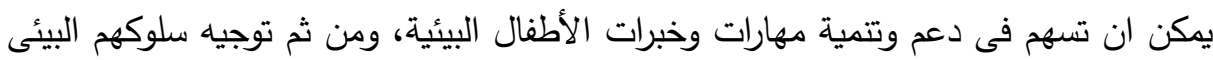
توجيها سليما مما ينعكس على المجتمع وعلى البيئة ككل.

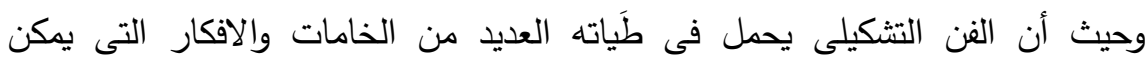

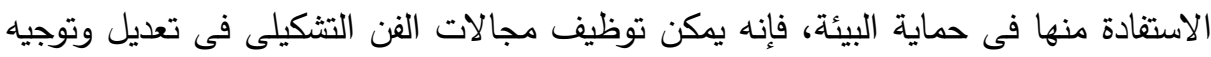

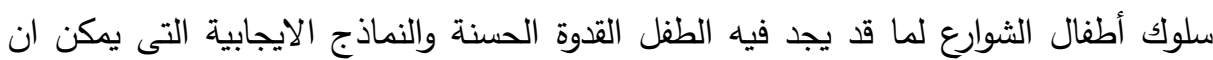
يقتىى بسلوكياتها ويتعلم منها ليحافظ على الموارد من الاستنزاف. 


$$
\begin{aligned}
& \text { مجلة العلوم البيئية } \\
& \text { معهد الدراسات والبحوث البيئية - جامعة عين شمس } \\
& \text { نهلة صلاح علي وآخرون }
\end{aligned}
$$

\section{همهني البهمث}

هدف البحث الحالى الى محاولة تعديل السلوك البيئى لدى عينة من أطفال الثوارع

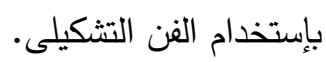

\section{المسيخالمبهي}

الأهمية النظرية: تكمن أهمية البحث من الناحية النظرية فى: • التعرف على أهم العوامل النفسية والبيئية والاجتماعية التى تقفي لفئ خلف مشكلة أطفال الشوارع. • الوصول الى فهم أعمق لثخصية اطفال الثوارع - عينة البحث- كل على حدا من خلال دراسة الحالة ومن ثم تحديد أكثر الوسائل التى يمكن التخخل من خلالها مع هؤلاء

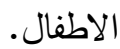
• الحد من وجود الاطفال فى الثوارع لما له من تاثيرا سلبيا على الفرد والمجتمع ككل وكذلك البيئة. • بالرغم من وجود العديد من الدراسات والبحوث السابقة التى أجريت فى مجال أطفال

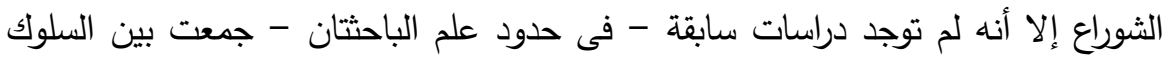
البيئى لدى اطفال الشوارع وبين الفن التثكيلى.

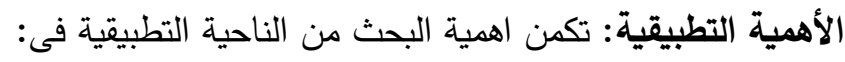

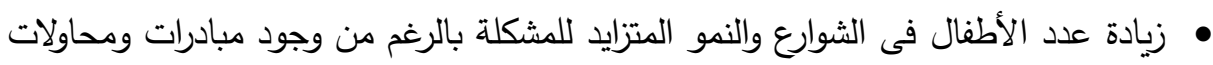
كثيرة من الجهات المجتمعية المختلفة. • محاولة الاستفادة من أطفال الثوارع عن طريق تعديل سلوكهم البيئى تمهيداً لدمجهم فى التى

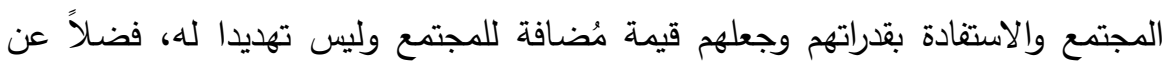
إتاحة الفرصة لهم للحياة مثل من هم فى نفس سِنهم.

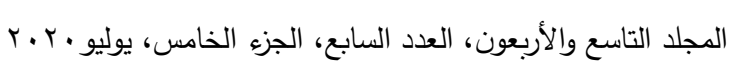


• إمكانية إستفادة الجهات المعنية بالطفولة والاطفال المشردين من نتائج هذا البحث فى تصميم وتتفيذ برامج متتوعة تشمل جميع الفئات من هؤلاء الأطفال وتوفير كافة سبل الرعاية من كافة الجوانب بما يحقق النمو والازدهار للدجتمع أولاً والبيئة ثانياً.

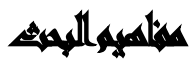

السلوك البيئى Environmental behavior: يعرف السلوك بأنه "كل ما يصدر عن الفرد من نشاط ظاهر كالكلام أو المشى، أو نشاط باطن كالتفكير والتذكر والتخيل، وذلك نتيجة التفاعل مع الاخرين". ولعل توجيه السلوك يهدف الى خلق الضبط الذاتى لدى الطفل وتعديل سلوكه غير

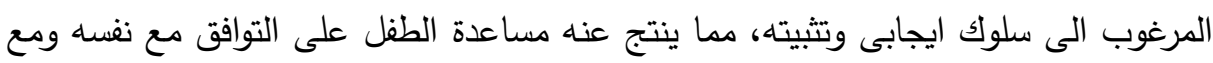

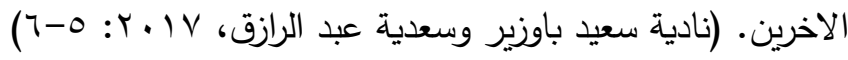
فالسلوك الانسانى متغير ومتطور ، حيث يعبر عن جميع أوجه النشاط الذى يقوم به الفرد لكى يتوافق ويتكيف مع العالم المحيط به سواء أشخاص أو اشياء وعناصر في في بيئته.

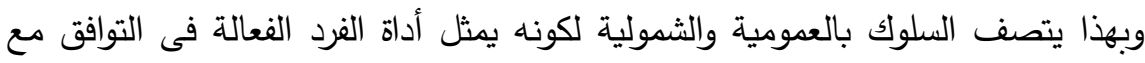

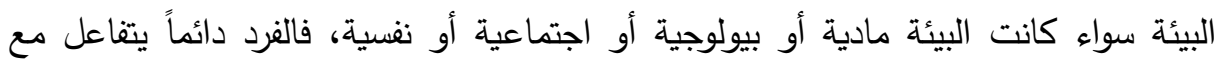

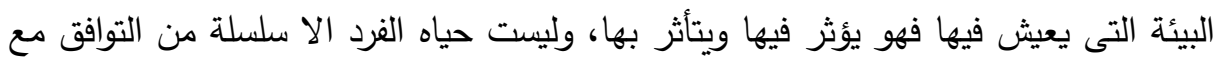

وبما أن ظروف ومقتضيات الحياة فى تغير دائم ومستمر لذلك يتعين على الفرد تعديل سلوكه كلما تغيرت ظروف البيئة التى يعيش فيها لإحداث نوع من التوازن. (طه عبد العظيه، (rq: r...

وهنا يجب الأخذ بعين الاعتبار التفاعل بين الفرد وبيئته، فالسلوك لا يحدث فى فراغ، بل لابد أن يحدث فى بيئة ما، وهذا يعنى أن السلوك يؤثر فى البيئة ويتاثر بها، فهو يشير الى لئي 108

$$
\begin{aligned}
& \text { المجلد التاسع والأربعون، العدد السابع، الجزء الخامس، يوليو . r. }
\end{aligned}
$$

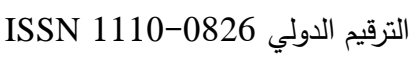


مجموعة الافعال والتصرفات التى تظهر فى استجابات الفرد تجاه بيئته. (جمال الخطيب، $(r \cdot: 199$.

وهكذا يتضح ان مفهوم السلوك البيئى يمثل إحدى مجالات السلوك البشرى بوجه عامحيث يشمل أى فعل أو تصرف فردى أو جماعى موجه مباشرة لعلاج أو حل القضايا

والمشكلات البيئية. (Negra \& Manning, 1997, 11) وفى ضوء ما سبق يمكن تعريف السلوك البيئى إجرائياً بانه "أى نثاط يقوم به طفل

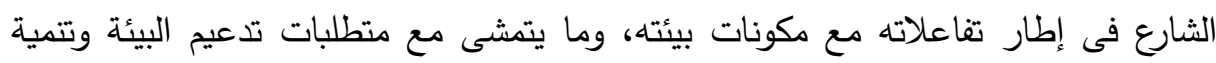
مواردها والحفاظ عليها واستدامتها".

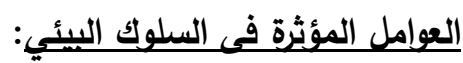
• عوامل ثثقافية: وتتضمن المستوى التعليمى والثقافى للطفل واسرته ومدى اهتمامهم بالمعارف والمعلومات والخبرات المرتبطة بالبيئة المحيطة بهم .

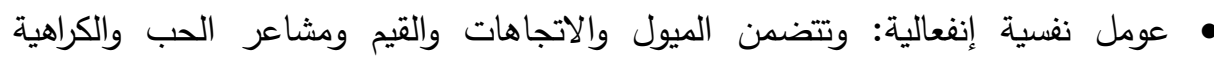

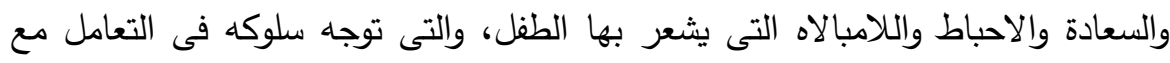
عناصر وموارد البيئة المحيطة به.

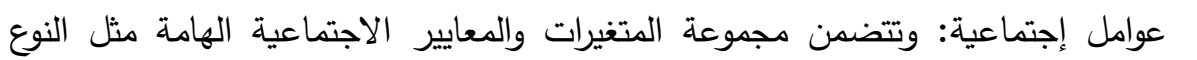
والعمر والمكانة الاجتماعية والقيم والعادات والتقاليد السائدة فى المجتمع الذى يعيش فيه الطفل. هالمؤسات الاجتماعية: التى تثارك فى تربية الطفل وتتشئته وبناء شخصيته فى كافة جوانبها والتى تتضمن المدرسة ووسائل الاعلام ودور العبادة والمؤسسات الرياضية. (نبيهة

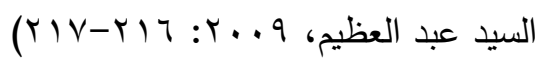
تعديل السلوك البيئي: يُعرف تعديل السلوك بأنه "إحداث تغيير هادف فى أنماط السلوك غير

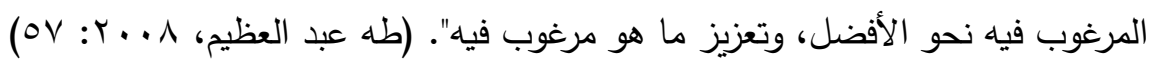

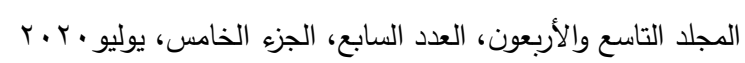




$$
\begin{aligned}
& \text { مجلة العلوم البيئية } \\
& \text { معهد الدراسات والبحوث البيئية - جامعة عين شمس لئس } \\
& \text { نهلة صلاح علي وآخرون }
\end{aligned}
$$

وفى تعريف آخر يُشار اليه بأنه "شكل من أشكال العلاج النفسي يهدف إلى تحويل السلوك غير المرغوب فيه إلى سلوك مرغوب وفق قواعد معينة، ويكون موضوع الاهتمام

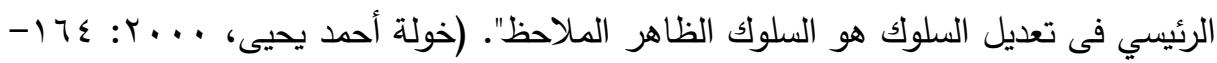

أى أن عملية تعديل السلوك تهدف الى تقوية السلوك المرغوب من جهة وإزالة السلوك غير المرغوب من جهة اخرى، وفى جوهرها تعتبر عملية محو تعلم وإعادة تعلم، حيث تتضمن

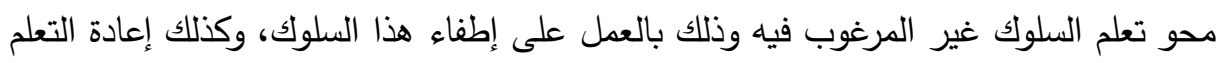
وإعادة التنظيم الإدراكي والسلوكى للمتعلم، والتعلم من جديد لأنماط سلوكية تحل محل الأنماط

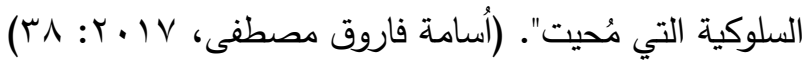
وبهذا يمكن تثكيل وإكساب الفرد منذ الطفولة السلوكيات والمهارات الجديدة غير لهات الموجودة لديه من خلال النمذجة والتدريب والتعزيز والاطفاء وصولا الى تعميم ممارسة السلوك وكي المرغوب فيه والحفاظ على إستمراره وممارسته كنمطاً سلوكياً فى مواقف الحياة المختلفة. فالسلوكيات المقبولة التى يتعلمها الطفل منذ الصغر لابد أن يعمم إستعمالها على مختلف مورديه البيئات، ويتقق ذلك مع النظرية السلوكية التى تؤكد على أهمية ودور البيئة فى نمو وتثكيل

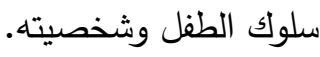
فالسلوك البيئى لدى الطفل هو فى الاصل سلوك ناتج عن العلاقة الدينامية التفاعلية بينه وبين بيئته، فضلا عن انه سلوك إجتماعى بالدرجة الاولى، فالبيئة الاجتماعية التى ينشأ

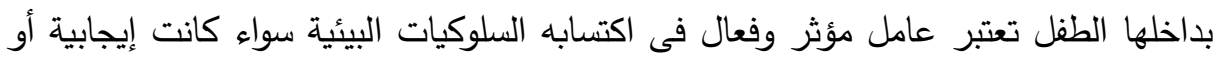
سلبية نتيجة لما تتسم به من خصائص وعوامل حضارية وثقافية وقيم وعادات وتقاليد ومعايير

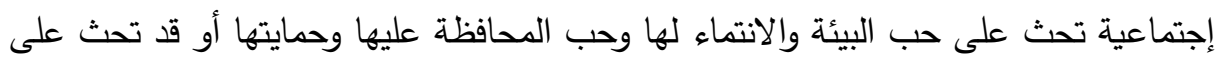
اللامبالاه والرغبة فى التدمير والإسراف. (نبيهة السيد عبد العظيم، و . . ؟ )

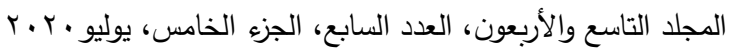

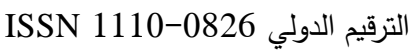




$$
\begin{aligned}
& \text { مجلة العلوم البيئية } \\
& \text { معهد الدراسات والبحوث البيئية - جامعة عين شمس لباس } \\
& \text { نهلة صلاح علي وآخرون }
\end{aligned}
$$

وفى ضوء ما سبق يمكن تعريف تعديل السلوك البيئى إجرائياً بأنه "عملية تعلم تهدف إلى ته

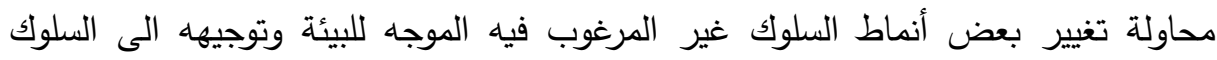

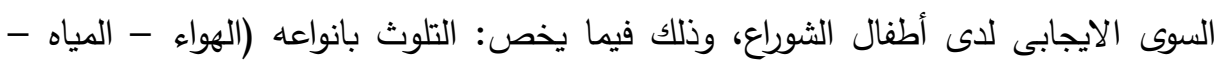
الغذاء - الضوضاء)، تدوير المخلفات، ترشيد إستهلاك (المياه - الطاقة)، النباتات والمحافظة ولنهاء عليها، النظافة (الثخصية، البيئية)، الإهتمام بالجانب الجمالى للبيئة، التدخين وأضراره، تلّئه والسلوكيات المتعلقة بالتعدى على البيئة". أطفال الثوارع Street children: تعددت التعريفات التى تتاولت أطفال الثوارع وان كان أغلبها تدور حول إحدى الصفات أو الخصائص التى تميز طفل الثارع، فيطلق عليهه:

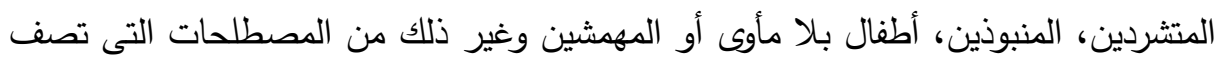
طفل الثارع. - مان. ووفقا لمنظمة الامم المتحدة يعرف طفل الثارع بأنه "الطفل ذكرا كان أو انثى والذى اتخذ من الشارع - بما يشتمل عليه المفهوم من أماكن مهجورة وأرصفة وكبارى وغيرها - محلا لعادي للاقامة والعيش دون أى رعاية أو رقابة أو حماية من قبل أشخاص بالغين الغين". (UNICEF Executive Board, 1986: 2)

وفى تعريف منظمة الصحة العالمية لأطفال الثوارع يعرفون بانهم"الاطفال المقيمون بالثارع وينقصهم الرعاية والحماية، وهم الاطفال المنفصلون عن اسرهم وينتقلون فى حماية مؤقتة بين اصدقائهم أو اماكن الرعاية المؤقته بالثارع، والذين لم يتبقى لهم صلة الثعائه مع اسرهم

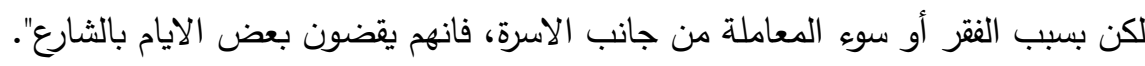

(World Health Organization,1993:7)

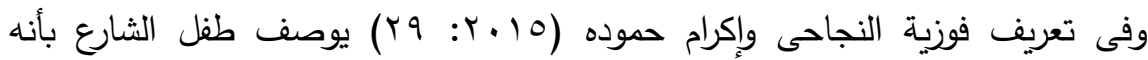

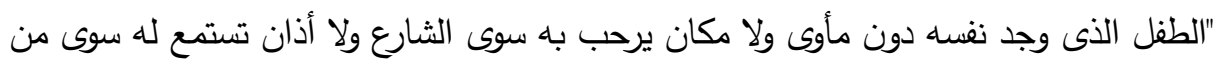
هم مثله، فهو الطفل الذى يعمل من أجل البقاء".

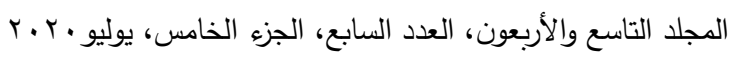

$$
\begin{aligned}
& \text { الترقيم الدولي 0826- ISSN 1110 }
\end{aligned}
$$


وهناك تعريف أكثر قدرة على تفسير المشكلة والدفع الى إيجاد حلول جذرية لها، وهو أن طفل الثارع هو "ذلك الطفل الذى عجزت اسرته عن إثباع حاجاته الاساسية الجسمية والنفسية والثقافية كنتاج لواقع إجتماعى إقتصادى تعايشه الاسرة، وفى إطار نظام إجتماعى إنى

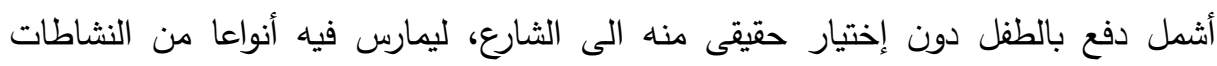
لإشباع حاجاته، من أجل البقاء، مما يعرضه للخطر والاستغلال والحرمان من ممارسه حقوقه دئه المجتمعية، وقد يعرضه للمسائلة القانونية بهدف حفظ النظام العام". (مجدى أحمد عبد الله،

وعلى غِرار ما سبق تخلص الباحثتان الى تعريفا إجرائيا لطفل الثارع بأنه "الطفل الذى

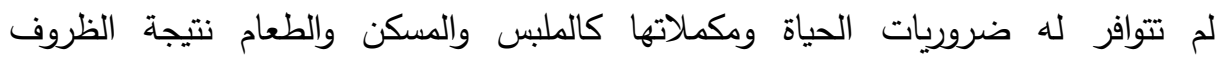

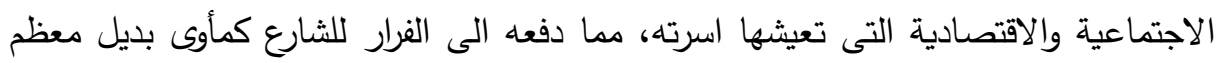
الوقت أو كل الوقت مما يعوقه عن الحصول على حقوقه المجتمعية". أسباب ظاهرة اطفال الشوارع:

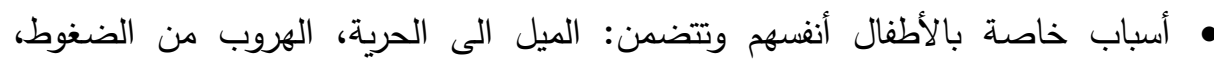
اللامبالاة من جانب الاسرة وعدم الاهتمام بالطفل، حب التملك والمغامرة، غياب الاهتمام

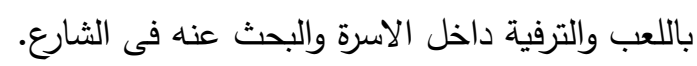
هأسباب اسرية وتتضمن: اليتم أى فقدان أحد الابوين أو كلاهما، الاقامة لدى الإى الاقارب،

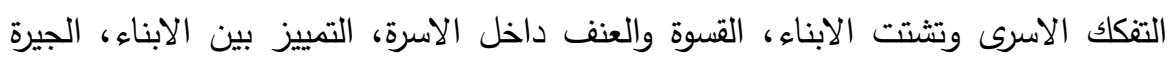

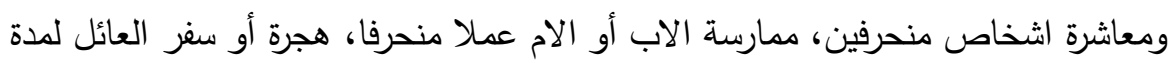

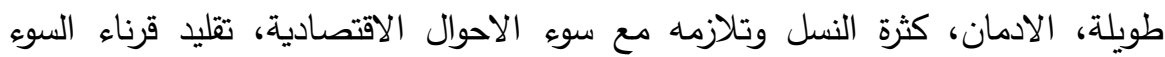
والرغبة فى العمل والكسب وتقليد الكبار . •أسباب إجتماعية وتتضمن: الهجرة من الريف الى المدينة، التسرب المدرسى واساليب التعليم المتشددة، الظروف الاقتصادية وعدم القدرة على توفير الحاجات الاساسية وتأمين

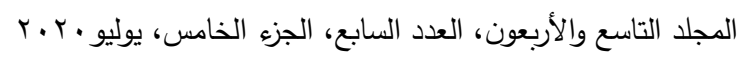

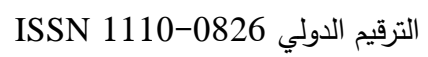




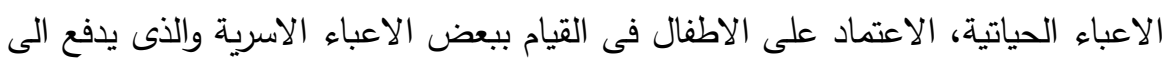

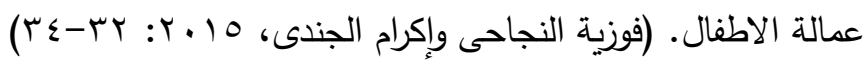

وتضيف الباحثتان الى ما سبق أن إخلال أحد الوالدين أو كلاهما بواجباتهما تجاه الابناء، وتفكك الاسرة بالطلاق أو وفاه أحد الوالدين أو تعدد الزوجات، ضعف التف التوجيه

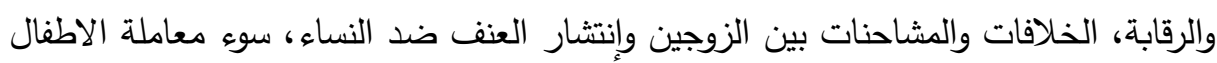
وردود الفعل العنيفة من الوالدين على سلوكهم، كلها عوامل يمكن ان تساعد على إستقحال الظاهرة.

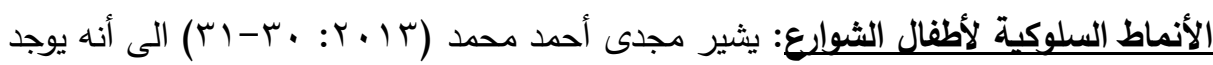
داخل أطفال الشوراع مشاعر عدائية تجاه المحيطين بهم والذين يتمثلون فى الاسرة باعتبارها

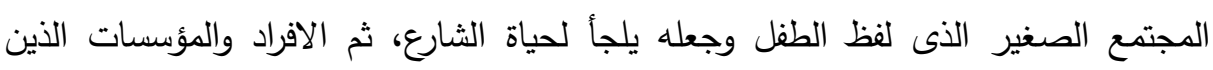

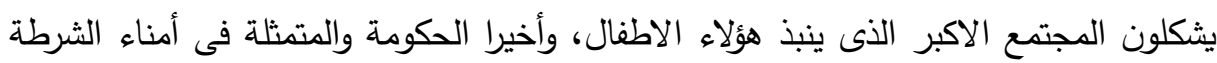
الذين يقومون بحملات الضبط فى الثوراع. وعلى أثر ذلك نجد أن الغالبية العظمى من أطفال الثوراع يعانون من العديد من المشكلات

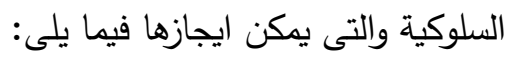
- إعتياد تكسير وتخريب الاشياء التى لا تخصهم بهدف إثارة الآخرين والتلذذ بشعورهم بالاذى ومحاولة حرمانهم مما لا يستطيعوا هم إمتلاكه.

$$
\text { - - - مب التعدام مبدأ الصواب والثغب والميول العدوانية. }
$$

- محدودية وتناقض القيم والاتجاهات، ففى الوقت الذى يمارس فيه طفل الثارع السلوكيات الخاطئة ضد الآخرين، نجد مشاعر التعاون والولاء والخوف والاهتمام المشترك بينهم تجاه 
الفن التشكيلى Plastit Art: الفن بشكل عام كلمة واسعة المعاني ولكنها في نفس الوقت

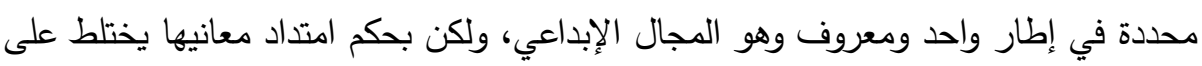

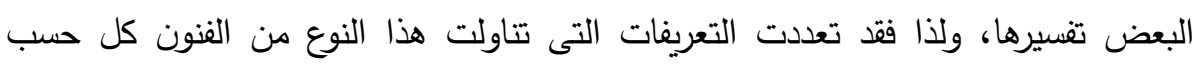

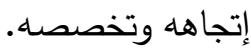

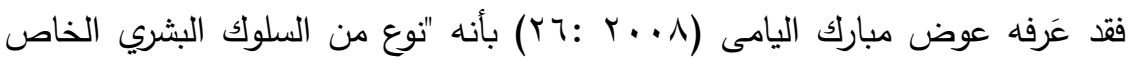

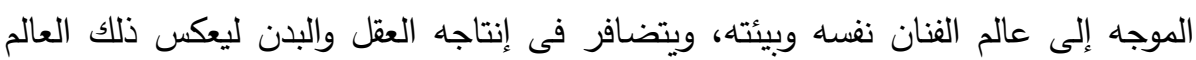

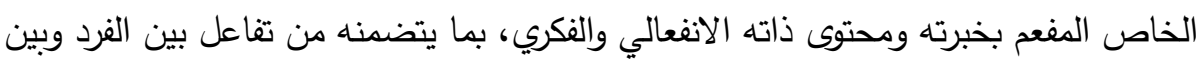
خامات فنه التثكيلية والذى يتضح من خلاله طريقة تفكيره وتفاعلاته الداخلية والخارجية". ويشمل مجالات عديدة منها الرسم، التصوير ، النحت، الأشغال وغيرها من المجالات.

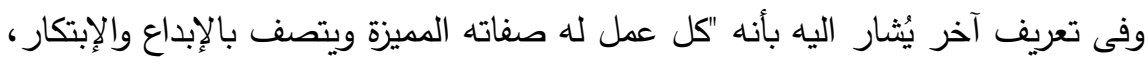

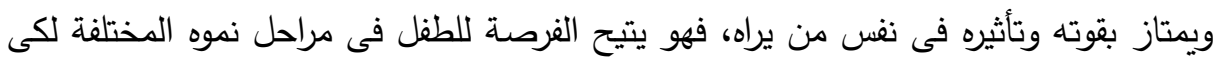

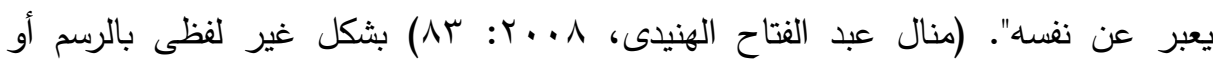

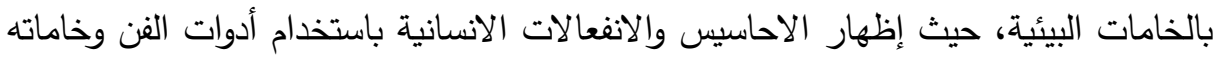

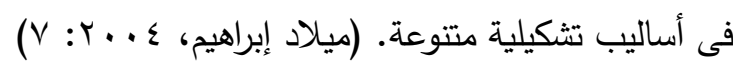

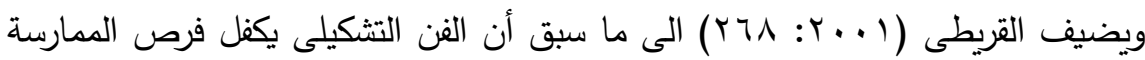

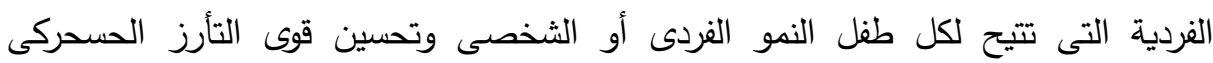
والانتباه والملاحظة والادراك والتمييز، كما يكفل فرص الانشطة الجماعية بما يشجع الاطفال

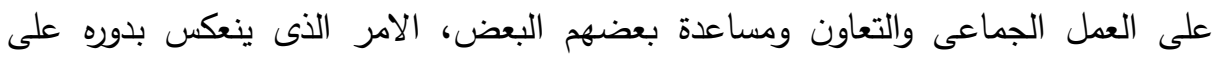

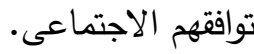
وهنا لابد من الربط بين مجالات الفن التثكيلى والبيئة المحيطة بالاطفال وباحتياجاتهم ورغباتهم لكى نضمن مشاركتهم بحماس ودافعية، بما يمكنهم من ادرالك قيمه البيئة ومواردها لهاليا وكيفية الحفاظ عليها من أجل الاستدامة.

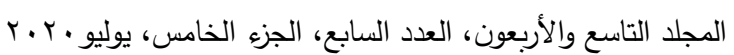

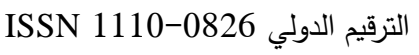




$$
\begin{aligned}
& \text { مجلة العلوم البيئية } \\
& \text { معهد الدراسات والبحوث البيئية - جامعة عين شمس لئس } \\
& \text { نهلة صلاح علي وآخرون }
\end{aligned}
$$

الفن التثكيلى فى ضوء النظرية السلوكية: وفقا للنظرية السلوكية فان الفن التشكيلى يمكن تتاوله كسلوك يمكن تعليمه وإكسابه للطفل، وذلك من خلال تتظيم الظروف البيئية اللازمة

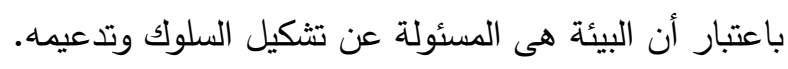
فالثكل النهائى للسلوك يتحدد نتيجة تفاعل الطفل مع بيئته، وينمو نتيجة التعزيز

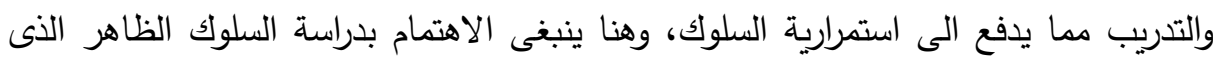

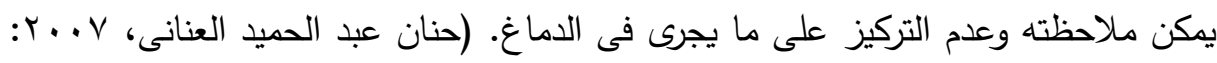

بيد أن الفن التثكيلي يعمل على تحرير الطفل من المشكلات النفسية، فالأطفال يحتاجون دائما إلى فرص تعبير عن أشياء كثيرة لم يختبروها من قبل ولم يعرفوها بعد، ولعل

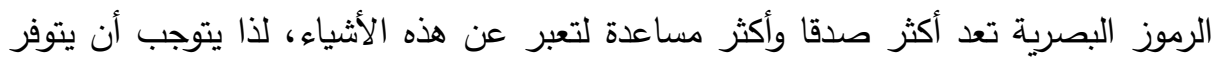
لهذا الطفل مقدار من الحرية ليؤكد استقلاليته وزيادة ثقته في نفسه بالإضافة إلى العمل على لهن تحريره من المشكلات النفسية والتى تملكت منه بفضل وجوده فى الثارع. (مصطفى عبيد،

أهمية الفن التشكيلى لأطفال الشوياع: إن الطفل عندما يبدأ حياته حرا طليقا ثم يتعرض شيئا

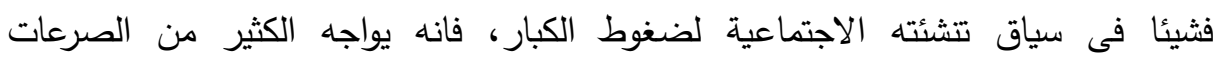

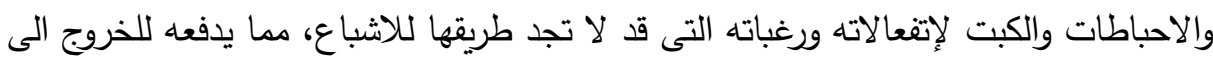

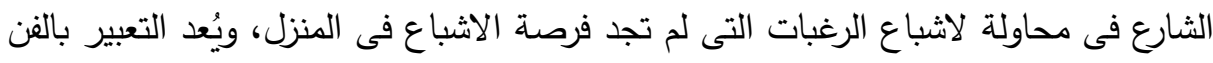

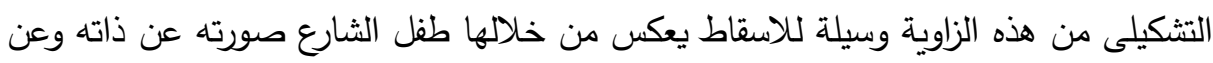

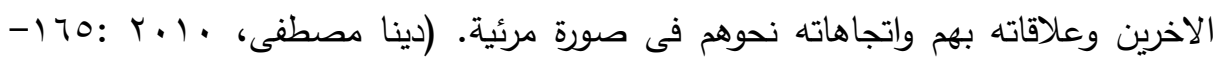

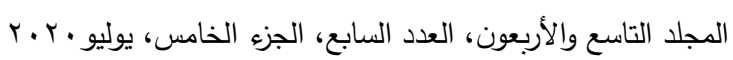

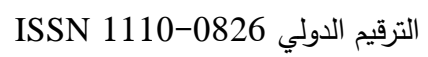


وبذلك يلعب الفن التشكيلى دوراً فعالاً في استعادة التوازن الانفعالي والتوافق الثخصي

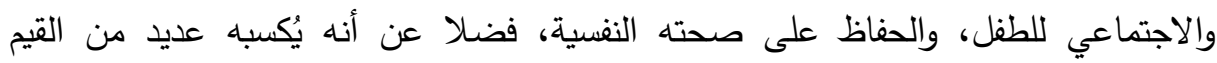

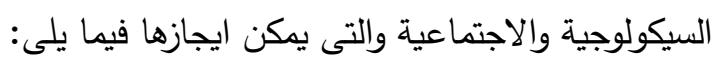

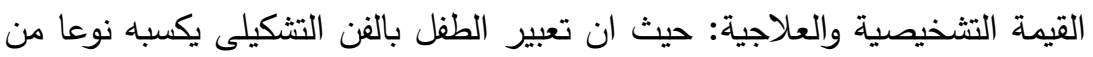
الحرية والتلقائية فى التعبير بصدق عما بداخله من صراعات انفعالية واهتمامات ومخاوف.

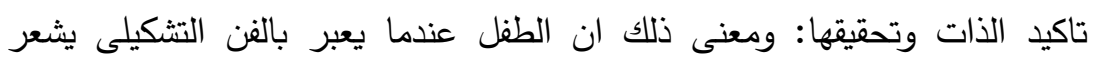

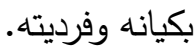

الإستمتاع الفنى: حيث يشعر الطفل اثثاء التعبير بالفن التشكيلى بالمتعة والبهجة والفرصة للاختيار والتى قد حرم منها نتيجة وجوده فى الثشارع.

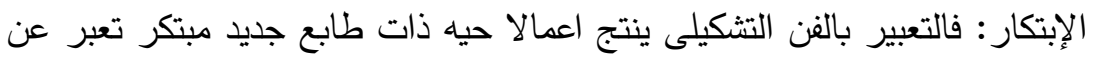
شخصية منتجها بغض النظر عن الطفل عادى أو طفل شارع. الايجابية الاجتماعية: حيث ان الفن التثكيلى يتيح الفرصة امام الطفل لنقل أفكاره

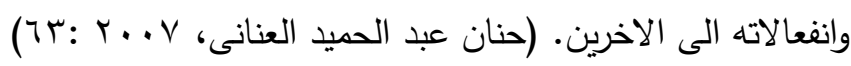
وفى ضوء ما سبق يمكن القول أن التعبير بالفن التثكيلى قد يجد فيه طفل الثارع سبيل التيل للتخفيف من الضغوط والمشاعر السلبية الواقعة عليه نتيجه تواجده فى الثارع، فوجود الطفل فى الثارع قد يكسبه العديد من الخبرات التى قد تفوق سنه ومرحلته العمرية، وهنا يلعب الفن

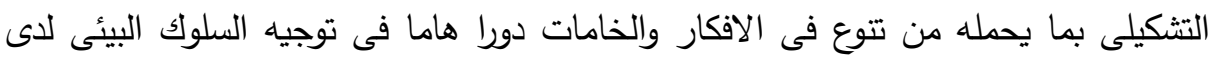
اطفال الثوارع، حتى ولو لم يحد من تلك الظاهرة، فعلى الاقل يجد الطفل سبيلا للنجاه. مجالات الفن التثكيلى التى يمكن إستخدامها مع أطفال الثوراع: هناك العديد من الأنشطة الفنية التى تتدرج تحت مظله الفن التشكيلى والتى يمكن أن تلائم الاطفال عموما وفئة أطفال

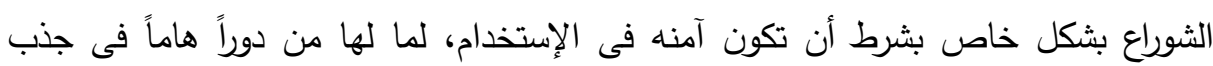


الاطفال أولا ثم إكتشاف قدراتهم ومهاراتهم وتثجيع نموهم الإدراكى وإكسابهم الخبرات والمهارات اليدوية بدافع التعلم.

وفيما يلى أمثلة على بعض مجالات الفن التثكيلى التى يمكن ان تؤتى ثمارها فى تعديل السلوك البيئى لدى أطفال الثوراع:

• الرسم والتصوير : ويتضمن الرسم بالخامات المختلفة (الأقلام- الطباشير - الوان الزيتأصابع اليد) على أنواع مختلفة ومتتوعة من الاسطح أو الأوراق أو اللوحات.

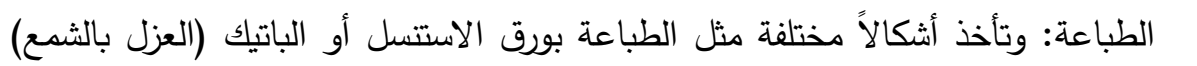
أو القوالب الخشبية أو المعدنية على الاقششة أو الآلواح المختلفة.

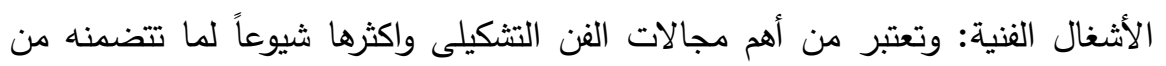

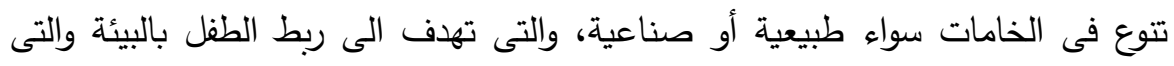
تتمثل فى: الجلود الطبيعية والصناعية والالياف والخيوط والفوم والبلاستيك ورقائق المعادن بانه

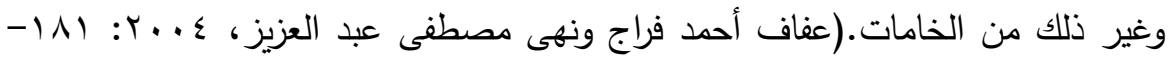

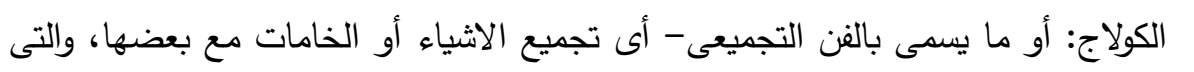

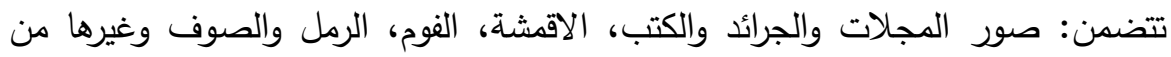

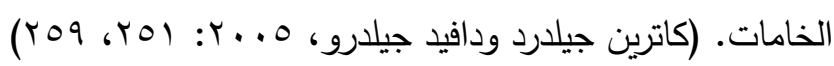

\section{الإلمالز المنظاريه}

فيما يلى عرض لبعض المداخل النظرية المفسرة لمشكلة أطفال الشوارع:

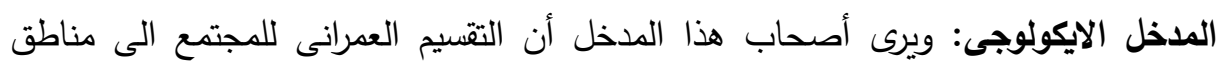

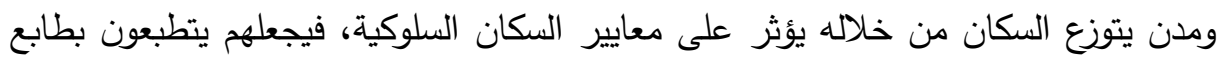

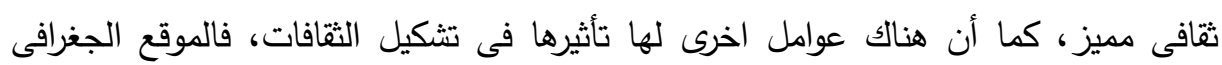

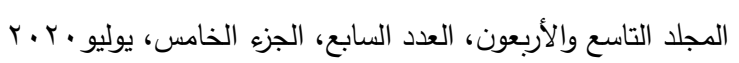

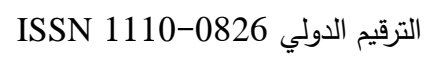


والمناخ والمستوى الصحى والمستوى التعليمى والصناعات والمواصلات لها تاثيرها القوى على

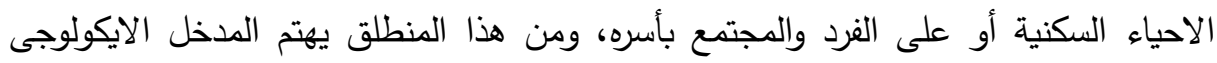
بدراسة العلاقة بين الانسان وبيئته من اجل الوقوف على طبيعة التفاعل بينهما وطبيعة باسته التأثيرات المتبادلة بينهما، ولذلك يمكن القول أن المناطق العشوائية تعتبر أماكن خصبة لهن للأمراض الإجتماعية كالتشرد والبغاء والعنف وغيرها.

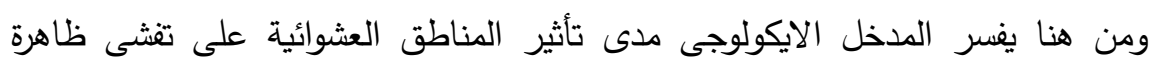

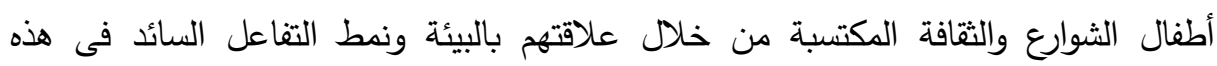

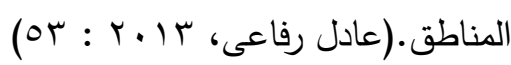
ومن ذلك نجد أن الظروف الاجتماعية والاقتصادية الذى يعيش فيها الطفل واسرته والتى

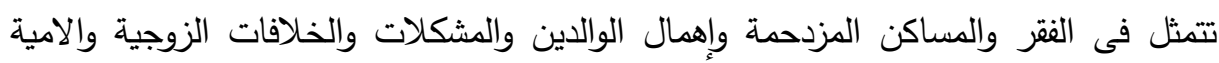
وفساد عملية التتشئة الاجتماعية - كلها عوامل رئيسية تنعكس على الطفل وعلى سلوكه، فالغالبية العظمى من أطفال الثوارع يعيشون فى مناطق فقيرة عشوائية ومتدهورة قد تكون

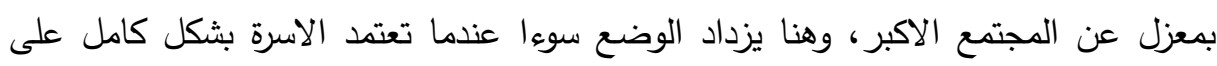
الطفل فى تلبية احتياجاتها، فيلجا الطفل الى الثارع للعمل وقد يتطور الامر ليهرب الطئ الطفل

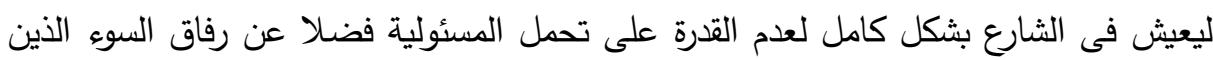
يمثلون عوامل جذب بالنسبة للطفل . نظرية التحليل النفسى: وتفسر هذه النظرية مشكلة أطفال الثوارع فى ضوء إساءة المعاملة، حيث أن العدوان الكامن فى اللاشعور لدى الاباء والامهات الذين تعرضوا فى طفولتهم لایى

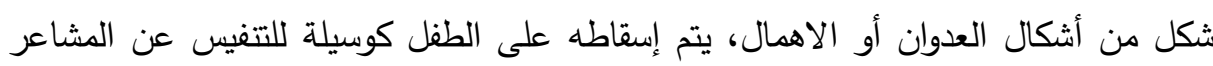
السلبية التى تكونت لدى الاب والام فى طفولتهم، وهو الامر الذى قد يؤدى الى هروب التى الطفل من القسوة والايذاء الذى يلقاهم من قبل الوالدين أو من يقوم مكانهما. (فوزية النجاحى وإكرام 
وبهذا فإن تعرض الوالدين فى طفولتهم لخبرات من الحرمان او القسوة او الاساءة يجعلهم

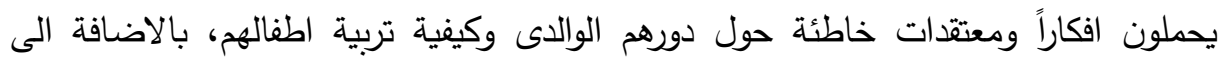

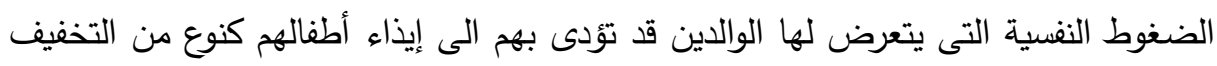
عن تلك الضغوط التى قد ترجع الى الاوضاع الاجتماعية والاقتصادية التى يعيشوها .

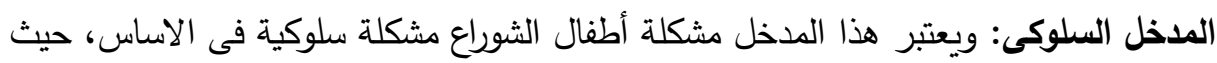
ان الانسان ابن البيئة بما تشمله من مثيرات واستجابات مختلفة، لها علاقة بمختلف مجالات

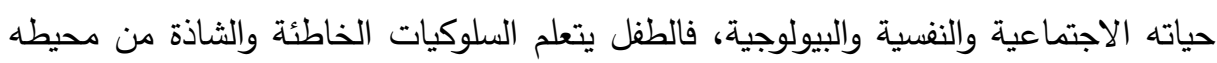
الاجتماعى عن طريق التعزيز والنمذجة وتثكيل وتسلسل السلوكيات غير فئم الدناسبة. (Kinyua, 2013 :27)

وبهذا المعنى يمكن إعتبار سلوك اطفال الشوارع سلوكا بيئيا الى حد كبير، من حيث

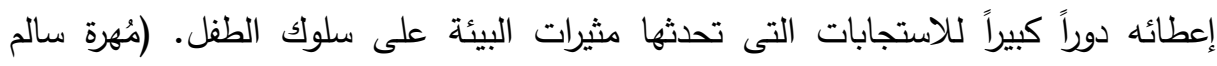
(VE: وفى ضوء ما سبق ترى الباحثتان أن أثكال الحرمان المختلفة التى يواجهها طفل الثارع

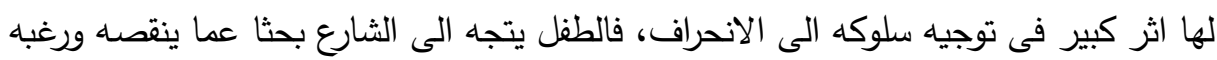

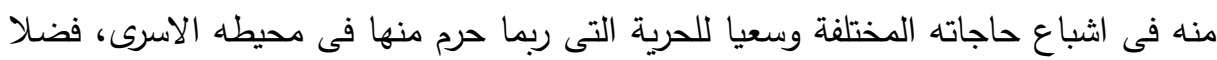
عن محاولة الطفل تقليد الآخرين. نظرية الحاجات: وتعتبر من النظريات الهامة التى قدمت تفسيراً لمشكلة أطفال الثوارع، حيث الثين

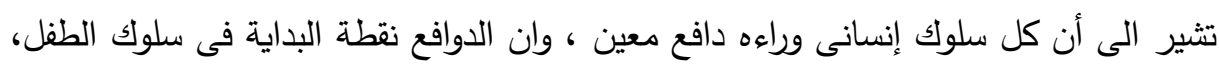

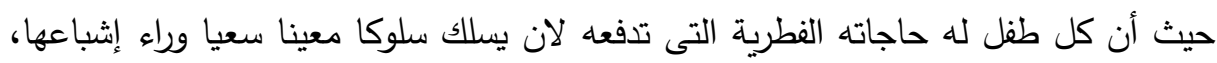
وتتدرج فى قوتها الى أعلى مستوى لها. وعلى ذلك فقد وضع "ماسلو" تنظيما للحاجات مرتبة ترتيبا هرميا، ومتدرجة من القاعدة الى القدة، حيث الحاجات الفسيولوجية أو البيولوجية فى قاعدة الهرم باعتبارها اقوى الحاجات

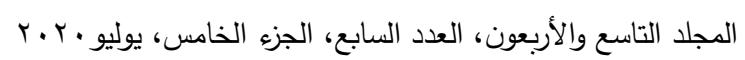

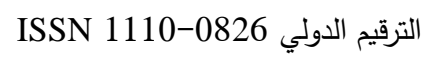


الانسانية وتثمل (الطعام، الماء)، يليها الحاجة للأمن (النفسى، المكانى والزمانى)، يليها

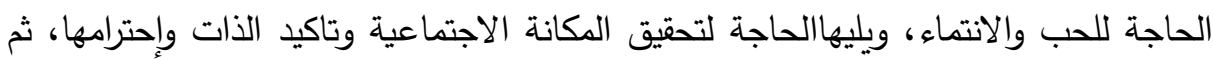

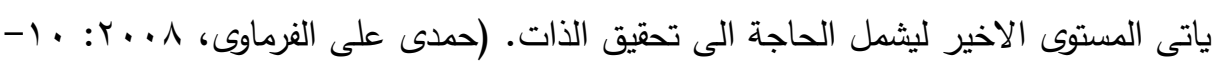

وتتقق الباحثتان مع ما سبق فى أن خروج الطفل الى الثارع يرتبط بدوافع قوية ومتتوعة، حيث تتتوع ما بين دوافع أولية مثل رغبة الطفل فى اشباع حاجاته الاساسية سواء كانت مادية

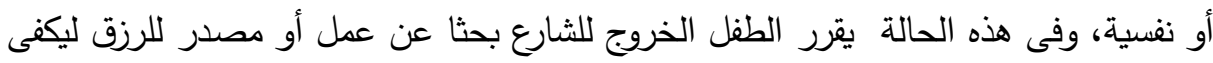
نفسه واسرته، أو قد تكون الدوافع ثانوية وتتمثل فى رغبة الطفل فى إكتساب الخبرات وتقليد

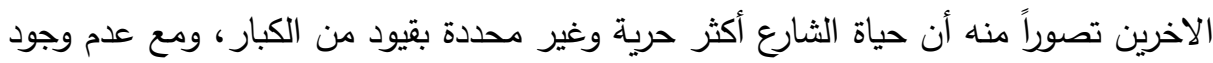

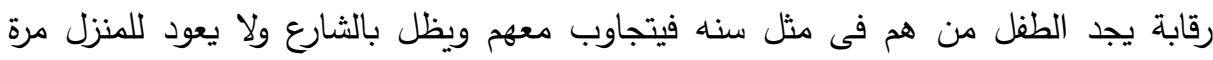
أخرى.

\section{المراسليه الملابه}

دراسات تناولت أطفال الثوارع: دراسة يحيى محمود النجار (Y P V): هدفت إلى التحقق من فاعلية برنامج إرشادي نفسي

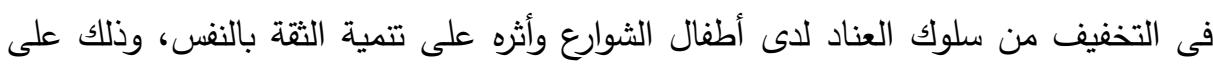

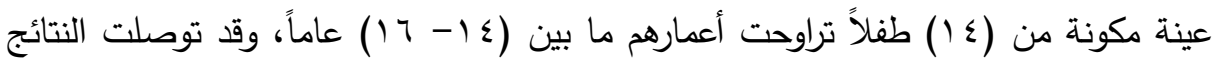
وجود فروق ذات دلالة إحصائية في العناد والثقة بالنفس بين القياسين القبلي والبعدي لدى ملى لـان

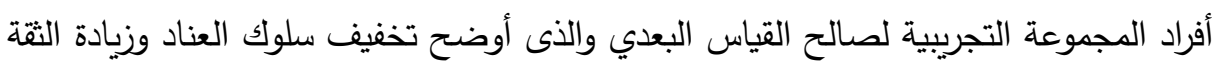

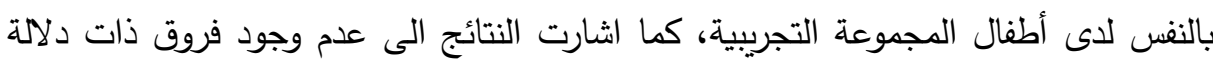
إحصائية في مقياسي العناد والثقة بالنفس بين القياسين البعدي والتتبعي لاى أفراد المجموعة التهات

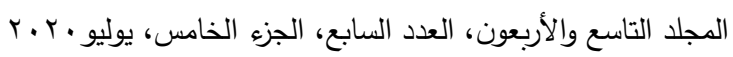

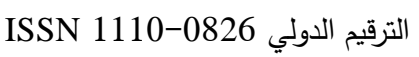


دراسة ليلى صبحى أمين فهمى (Y Y P): هدفت الى التحقق من فاعلية برنامج ارشادى

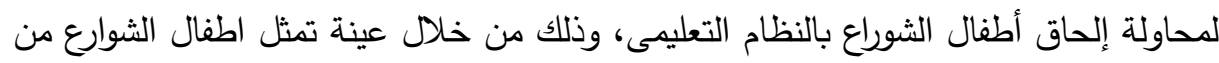

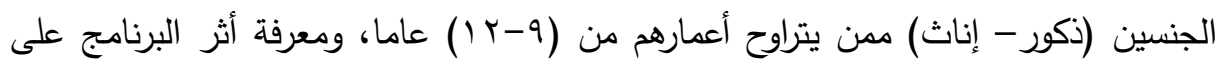

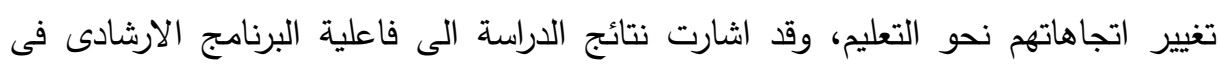

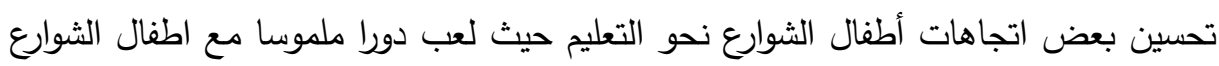
من خلال الجلسات الارشادية والفنيات المستخدمة فيه والانشطة المختلفة.

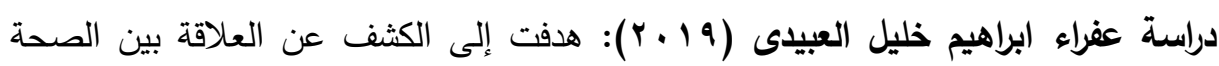

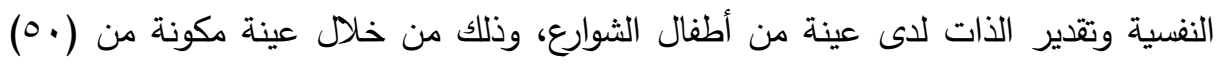

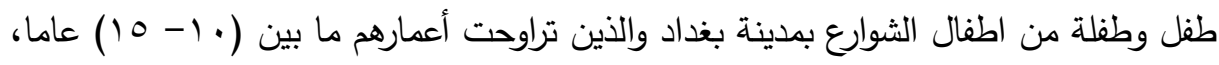
وقد اشارت النتائج الى إن أطفال الثوارع اظهروا مستوى منخفض في الصحة النفسية وكذلك الحال بالنسبة لتقدير الذات، فضلا عن وجود علاقة ارتباطية موجبة دالة إحصائيا بين الصحة النفسية وتقدير الذات. دراسة Endris, Sofiya; Sitota, Galata (9 1 × †): هدفت الى التحقق من حياه اطفال الشوارع والوقوف على الأسباب الرئيسية التي تجعل الأطفال يغادرون منازلهم للشوارع، وكذلك هن الكاه

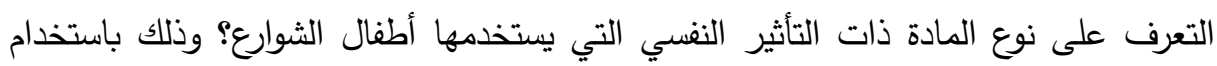

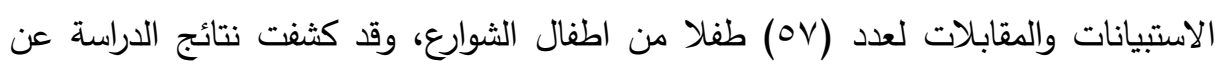

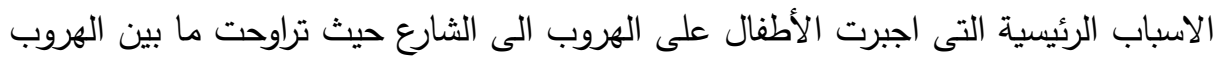

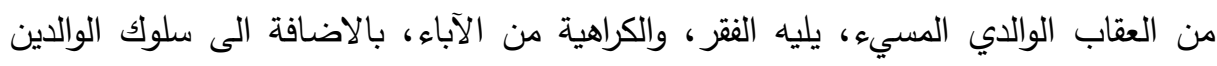

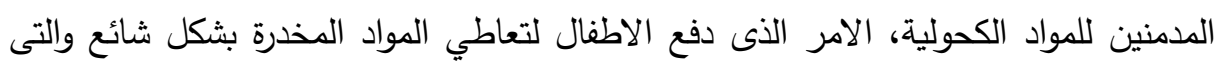
تضمنت استتشاق البنزين والماريجوانا والحشيش. دراسة أزهار علوان (19 (ب): هدفت الى معرفة دور العنف المدرسى فى انتثار ظاهرة اطفال الثوارع، وذلك من خلال عينة مكونة من (•0) طالب من طلاب المدارس الثانوية

$$
\begin{aligned}
& \text { المجلد التاسع والأربعون، العدد السابع، الجزء الخامس، يوليو . F. }
\end{aligned}
$$

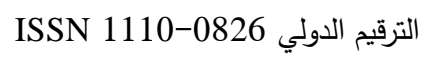


بمحافظة بغداد، وقد أشارت نتائج الدراسة الى أن الظروف الاجتماعية والقهر النفسى

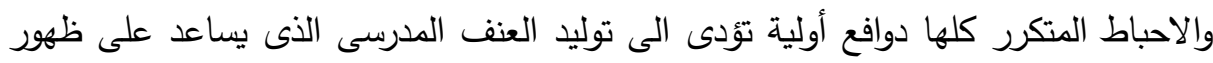
وانتشار ظاهرة اطفال الثوارع نتيجة تسرب الاطفال والطلاب من المدرسة. دراسات تناولت الفن التشكيلى وأثره على الاطفال:

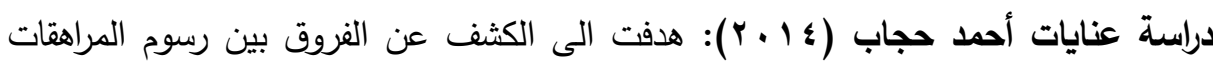
العاديات وفتيات الثارع الأمهات، مع بيان العلاقة بين تلك الرسوم ومشكلاتهن النفسية من هن خلال دراسة حالاتهن، وقد تكونت العينة من مجموعتين حيث (0) حالات للاراسة من فتيات الثارع الامهات و(0) حالات من المراهقات العاديات بالمرحلة الاعدادية والثانوية، وقد اشارت نتائج دراسة الحالات الى وجود فروق بين رسوم العينتين حيث عبرت الفتيات العاديات عن عناصر الرسم بسكل سوى، فى حين عينة الامهات الصغيرات عبرن عن الصورة الصيئة المختزنة بداخهم انعكاسا لما يعانونه من مشكلات نفسية نتيجة للتنكك الاسرى وعدم الترابط والعلاقات الاسرية السيئة، حيث بدا ذلك فى الشخصيات المتناثرة بالصفحة غير المكتملة دراسة جيهان ماهر طه جنيدى (10 ب ب): هدفت الدراسة الى الكثف عن فاعلية برنامج قائم على العلاج بالفن في تعديل سلوك أطفال الروضة، وقد تكونت عينة الدراسة من (·r) طفل وطفلة من أطفال الروضة في منطقة الجوف، وقد توصلت نتائج الدراسة الى فاعلية برنامج العلاج بالفن فى تعديل سلوك الاطفال، حيث وجدت فروق ذات دلالة إحصائية بالنسبة

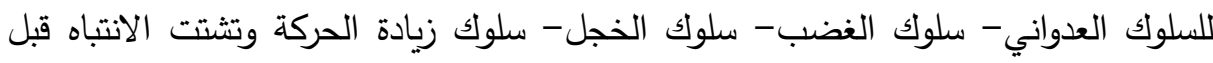
وبعد تطبيق البرنامج لصالح التطبيق البعدي مما يدل على فاعلية البرنامج.

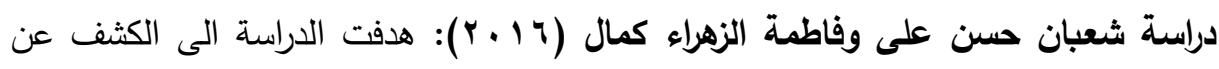
العلاقة بين إدمان الإنترنت وبعض الإضطرابات السلوكية وقياس فاعلية برنامج مقترح قائم على الأنثطة الفنية في علاج إدمان الإنترنت والإضطرابات السلوكية، وقد تكونت عينة الإندان 122

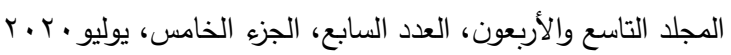

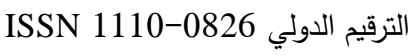


الدراسة من (7) أطفال ممن تراوحت أعمارهم ما بين (11-0 (1) سنة، وقد توصلت نتائج الدراسة الى وجود علاقة ارتباطية موجبة دالة إحصائيا بين إدمان الإنترنت والإضطرابات

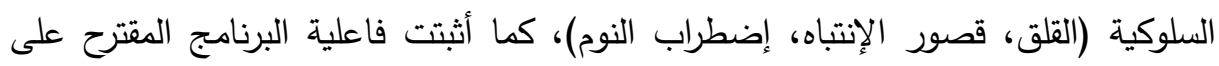
علاج إدمان الإنترنت وتلك الإضطرابات السلوكية.

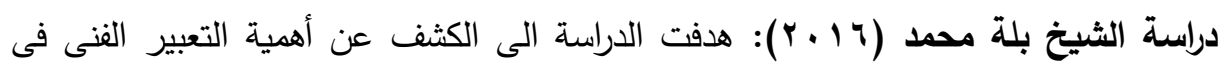
حياة الاطفال، ودراسة فعالية استراتيجية التعبير الفنى التثكيلى فى تعديل سلوك المضطبه لهبين والاعتراف بحرية التعبير لديهم كباقى افراد المجتمع، وقد تضمنت العينة مجموعة من الاطفال ممن تتراوح اعمارهم ما بين (11-؛ (1) سنة بولاية تلمسان، وقد تم تحليل رسوم الاطفال نفسيا واجتماعيا، وقد اشارت نتائج الدراسة الى اهمية معرفة خصائص وسمات التعبير الفنى للطفل فى هذه المرحلة ومدى التطور الذى يتلقاه الاطفال فى شخصيتهم ونموهم النفسى والابداعى مدئه وسهولة التعامل معهم.

دراسة منى بنت عبد الله بن إبراهيم (19 ـ ؟): هدفت الى التحقق من فاعلية برنامج إثرائى

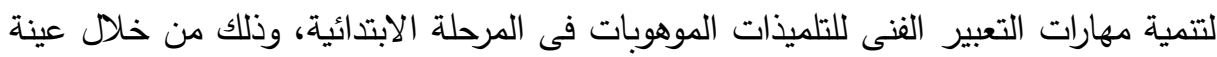
قوامها (·r) تلميذة من الموهوبات فى التعبير الفنى فى الصفين الرابع والخامس الابتدائى

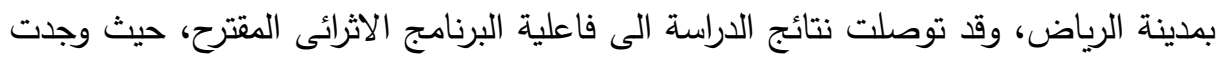

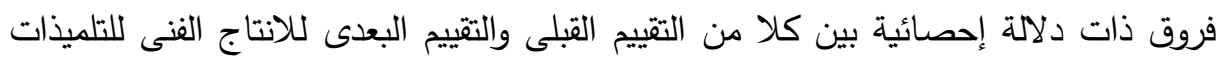
عينة الدراسة لصالح التقييم البعدى. تعقيب على الاراسات السابقة: فى ضوء العرض السابق للدراسات والبحوث التى تتاولت متغيرات البحث الحالى يتضح: • مدى أهمية البرامج الإرشادية فى تخفيف بعض المشكلات السلوكية لاى أطفال الثوارع

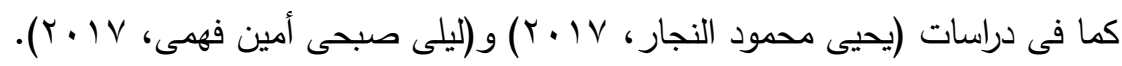

$$
\begin{aligned}
& \text { المجلد التاسع والأربعون، العدد السابع، الجزء الخامس، يوليو •. r. } \\
& \text { الترقيم الدولي 0826- ISSN 1110 }
\end{aligned}
$$




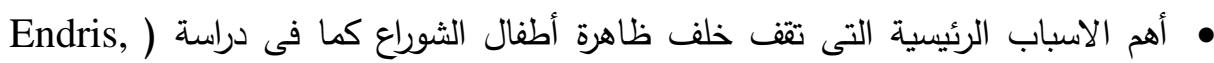
( $r$. 19 ،Sofiya; Sitota, Galata • تاثير العنف المدرسى على انتشار ظاهرة اطفال الثوراع كما فى دراسة (أزهار علوان، $\cdot(r+19$ • العلاقة بين الصحة النفسية وتقدير الذات لدى أطفال الثوارع كما فى دراسة (عفراء ابراهيم

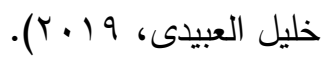
• أهمية التعبير الفنى وبرامج العلاج بالفن فى الكثف عن المشكلات النفسية والإضطرابات

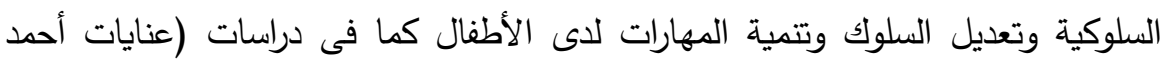

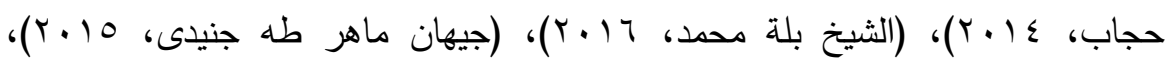

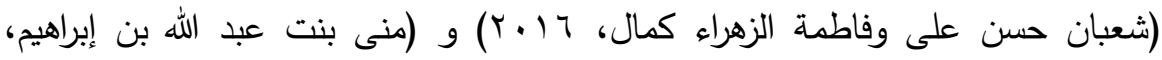
$\cdot(r \cdot 19$ يتضح مما سبق انه لم توجد دراسة - فى حدود علم الباحثتان - جمعت بين أطفال

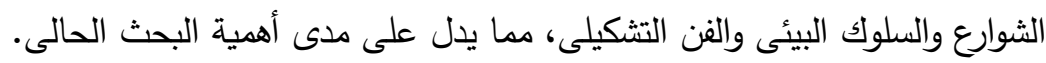

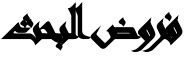

() توجد فروق ذات دلالة إحصائية بين متوسطات درجات أطفال الثوراع على أبعاد مقياس السلوك البيئى بعد إستخدام الفن التشكيلى فى القياسين القبلى والبعدى فى إتجاه القياس

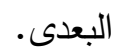
r) لا توجد فروق ذات دلالة إحصائية بين متوسطات درجات أطفال الثوارع على أبعاد مقياس السلوك البيئى بعد إستخدام الفن التشكيلى فى القياسين البعدى والتتبعى.

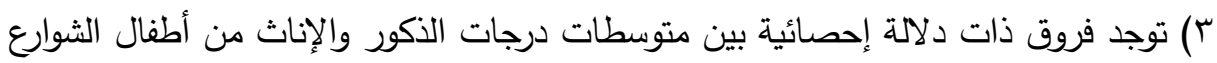
على أبعاد مقياس السلوك البيئى.

$$
\begin{gathered}
\text { المجلد التاسع والأربعون، العدد السابع، الجزء الخامس، يوليو • ب. الترقيم الدولي 0826- } \\
\text { ISSN 1110 }
\end{gathered}
$$


ء) توجد علاقة ارتباطية ذات دلالة إحصائية بين المستوى الإجتماعى الإقتصادى للأسرة وخروج الأطفال إلى الثارع.

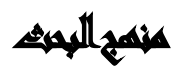

إعتمد البحث الحالى على المنهج شبه التجريبى بصورتيه القياسية (القبلى- البعدى) والذى تضمن المتغيرات التالية: - التئ المتغير المستقل: إستخدام الفن التشكيلى. المنئ. المتغير التابع: تعديل السلوك البيئى لاى عينة من أطفال الثوراع.

\section{Andinis}

تكونت عينة البحث الحالى من (•r) طفل وطفلة من أطفال الثوارع، بواقع (1/) ذكور

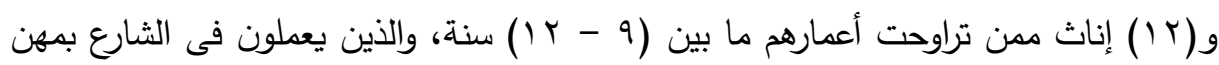
مختلفة (مسح السيارات - بيع المناديل - سايس جراج - التسول).

\section{Andlatad}

إستمارة دراسة الحالة (إعداد الباحثتان): تم تصميم إستمارة دراسة الحالة كأداة لجمع البيانات وتحديد عينة البحث، وقد إثتملت الإستمارة على العناصر التالية:

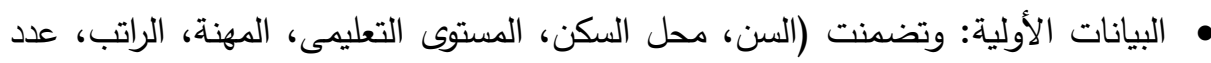

$$
\text { ساعات العمل). }
$$

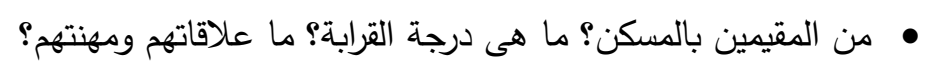

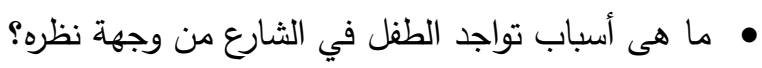
• كيف يرى الطفل الحياة بالثارع؟

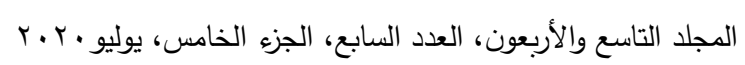

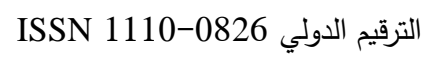




$$
\begin{aligned}
& \text { مجلة العلوم البيئية } \\
& \text { معهد الدراسات والبحوث البيئية - جامعة عين شمس لباس } \\
& \text { نهلة صلاح علي وآخرون }
\end{aligned}
$$

$$
\text { • • هيف يقضي وقته في الثارع؟ القبض عليه من قبل؟ }
$$

• ما هى ظروف البيئة الإجتماعية والإقتصادية الذى يعيش فيها فئ الطفل؟

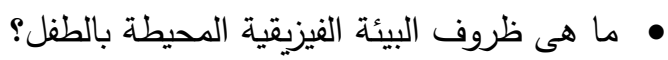

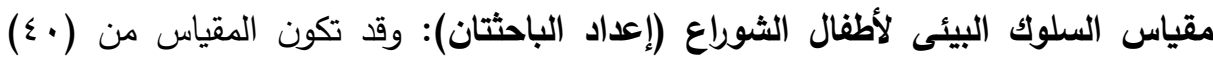

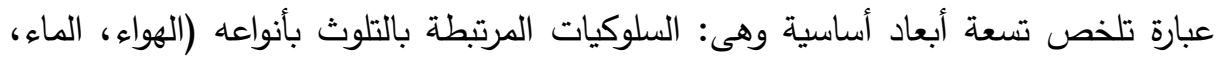

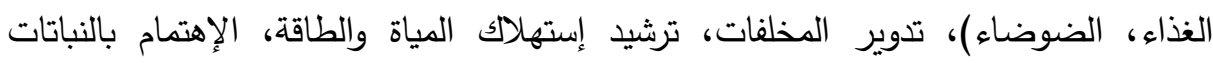
والمحافظة عليها، سلوكيات النظافة (الثخصية، البيئية)، الجانب الجمالى للبيئة، التدخين وأضراره، التعدى على البيئة. وللتحقق من ثبات المقياس تم استخدام معادلة ألفا كرونباخ (Alpha Cronbach)،

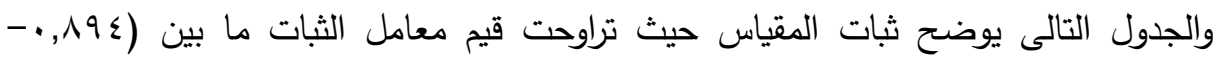

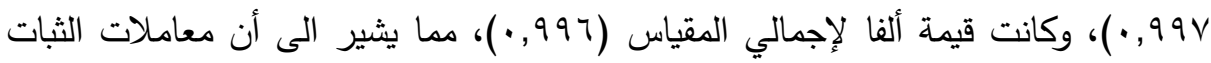

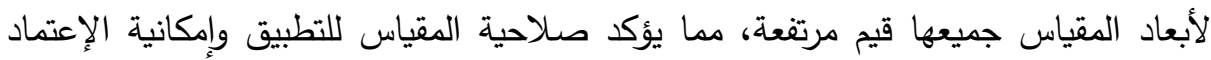

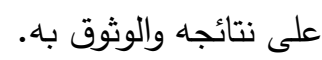

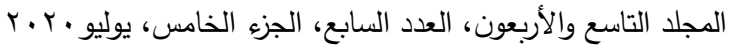

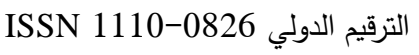




$$
\begin{aligned}
& \text { مجلة العلوم البيئية } \\
& \text { معهد الدراسات والبحوث البيئية - جامعة عين شمس لبع } \\
& \text { نهلة صلاح علي وآخرون }
\end{aligned}
$$

\begin{tabular}{|c|c|c|}
\hline معامل ثبات ألفا & عدد المواقف & أبعاد المقياس \\
\hline$\cdot, \wedge 9 \leq$ & Ir & التلوث بأنواعه \\
\hline$\cdot, 9 Y \mathrm{r}$ & $r$ & تدوير المخلفات \\
\hline$\cdot, 99 \mathrm{~V}$ & $r$ & ترشيد استهلاك المياه \\
\hline$\cdot, 9 Y Y$ & r & ترشيد استهلالك الطاقة \\
\hline$\cdot, 9 \wedge r$ & $r$ & الإهتمام بالنباتات والمحافظة عليها \\
\hline$\cdot, 9 Y Y$ & $\varepsilon$ & النظافة (الثخصية، البيئة) \\
\hline$\cdot, 99 \mathrm{~V}$ & $r$ & الإهتمام بالجانب الجمالى للبيئة \\
\hline$\cdot, \wedge \wedge \varepsilon$ & r & أضرار التدخين \\
\hline$\cdot, 917$ & $\wedge$ & التعدى على البيئة \\
\hline., 997 & $\varepsilon$. & إجمالى المقياس \\
\hline
\end{tabular}

جلول (1): ثبات العبارات لمقياس السلوك البيئى

وللتحقق من صدق المقياس تم حساب معامل الإتساق الداخلى ومعامل الإرتباط المصحح لكل بعد من أبعاد المقياس لحساب الإرتباط بين كل بعد والدرجة الكلية على الإنى

\begin{tabular}{|c|c|c|c|}
\hline معامل التصحيح & الدلالة المعنوية & معامل ارتباط بيرسون & أبعاد المقياس \\
\hline., 00 & $\cdot, \cdot \varepsilon$ & 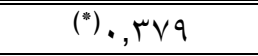 & التلوث بأنواعه \\
\hline$\cdot, \wedge$. & $\cdot, \ldots 1$ & $(* *),, 771$ & تدوير المخلفات \\
\hline.,$\pi$ & $\cdot, \cdot r$ & (*).,,$\leqslant \leqslant V$ & ترشيد استهلاك المياه \\
\hline$\cdot, 71$ & $\cdot, \cdot r$ & $\left({ }^{*}\right) \cdot, \leq \leqslant \leq$ & ترشيد استهلاك الطاقة \\
\hline$\cdot, 4$ & $\cdot, \cdot \varepsilon$ & $\left({ }^{*}\right) \cdot, \sum Y \uparrow$ & الإهتمام بالنباتات والمحافظة عليها \\
\hline 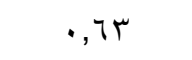 & $\cdot, \cdots 9$ & $(" *) \cdot,, \leq 7 \leq$ & النظافة (الثخصية، البيئة) \\
\hline$\cdot, V T$ & $\cdot, \ldots 1$ & $(* *) \cdot, 09 \varepsilon$ & الإهتمام بالجانب الجمالى للبيئة \\
\hline$\cdot, V 7$ & $\cdot, \ldots 1$ & $(* *) \cdot, 7 \cdot \Lambda$ & أضرار التدخين \\
\hline$\cdot, 91$ & $\cdot, \ldots 1$ & $(* *) \cdot, \wedge \curlyvee \wedge$ & التعدى على البيئة \\
\hline
\end{tabular}

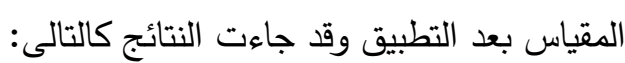
جدول (ץ): صدق الإتساق الداخلى لعبارت مقياس السلوك البيئى

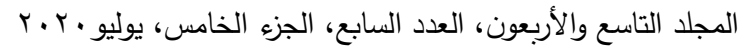
127

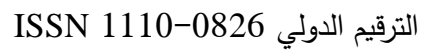




$$
\begin{aligned}
& \text { مجلة العلوم البيئية } \\
& \text { معهد الدراسات والبحوث البيئية - جامعة عين شمس لئه } \\
& \text { نهلة صلاح علي وآخرون }
\end{aligned}
$$

يتضح من الجدول السابق أن قيم معامل الإرتباط دالة إحصائياً، حيث بلغ عند مستوى (ه) معنوية (0., • ) مما يؤكد على صدق الإتساق الداخلي لأبعاد المقياس، وللمزيد من التحليل تم

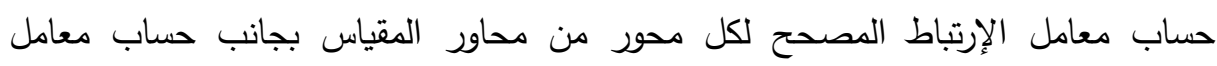

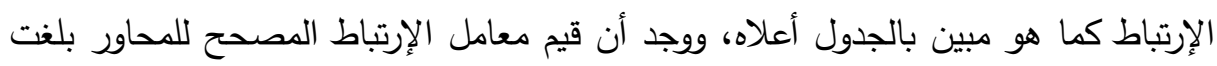

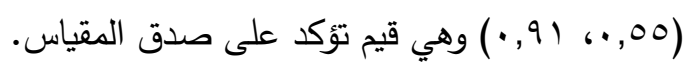

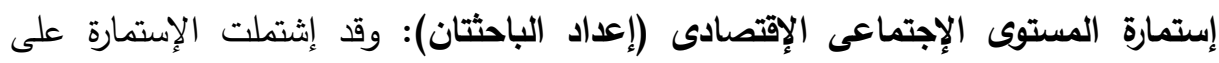

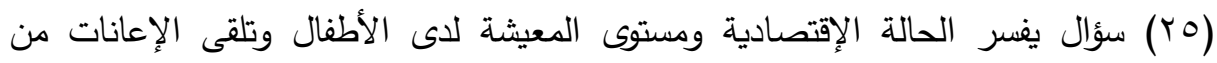
عدمه، إلى جانب بعض الأسئلة الخاصة بالمستوى الإجتماعى كعمل الوالدين والأخوة وغيره، كما اشتملت الإستماره على عدة أسئلة تقترب من بيئة الأطفال ومعارفهم.

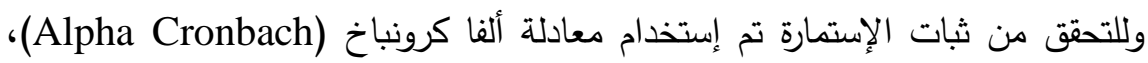

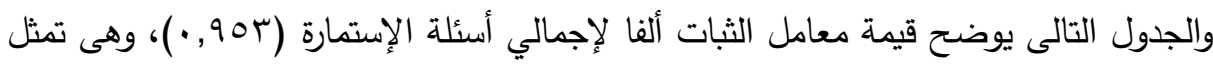
قيمة مرتفعة، مما يثير إلى صلاحية الإستمارة للتطبيق وإمكانية الاعتماد على نتائجها

\begin{tabular}{|c|c|c|}
\hline معامل ثبات ألفا & عدد العبارات & إستمارة المستوى الإجتماعى الإقتصادى \\
\hline$\cdot, 904$ & ro & الدرجة الكلية \\
\hline
\end{tabular}
والوثوق بها. جدول (ץ): قيمة معامل الثبات بطريقة ألفا كرونباخ

وللتحقق من صدق الإستمارة تم عرض بنود الإستمارة على مجموعة من المحكمين للتأكد من مناسبة بنود الإستمارة لما وضعت لقياسه بالنسبة للمرحلة العرية التى ينتمى إليها الأطفال.

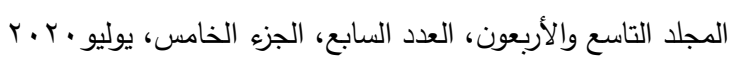

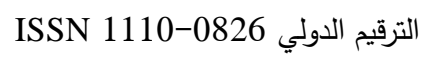


مجلة العلوم البيئية

معهد الدراسات والبحوث البيئية - جامعة عين شمس البية

نهلة صلاح علي وآخرون

جدول (؛): خطة عمل البحث

\begin{tabular}{|c|c|c|c|c|}
\hline الزمن & نماذج من التطبيقات العملية & الفن التشكيلى & عنوان ورشة العمل & الاسبوع \\
\hline ساعتان & & أشغال فنية & السلوكيات المرتبطة & الأول \\
\hline ساعتان & & تصوير & المرتبطة بالتلوثيات: & 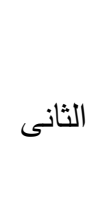 \\
\hline ساعتان & -1 & أشغال فنية & ت - - - مخلفير المخلفات: - مخلفات & الثالث ل \\
\hline
\end{tabular}

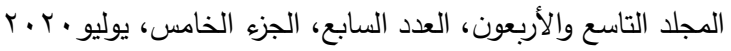

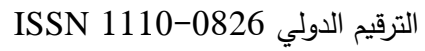


مجلة العلوم البيئية

معهد الدراسات والبحوث البيئية - جامعة عين شمس لباس

نهلة صلاح علي وآخرون

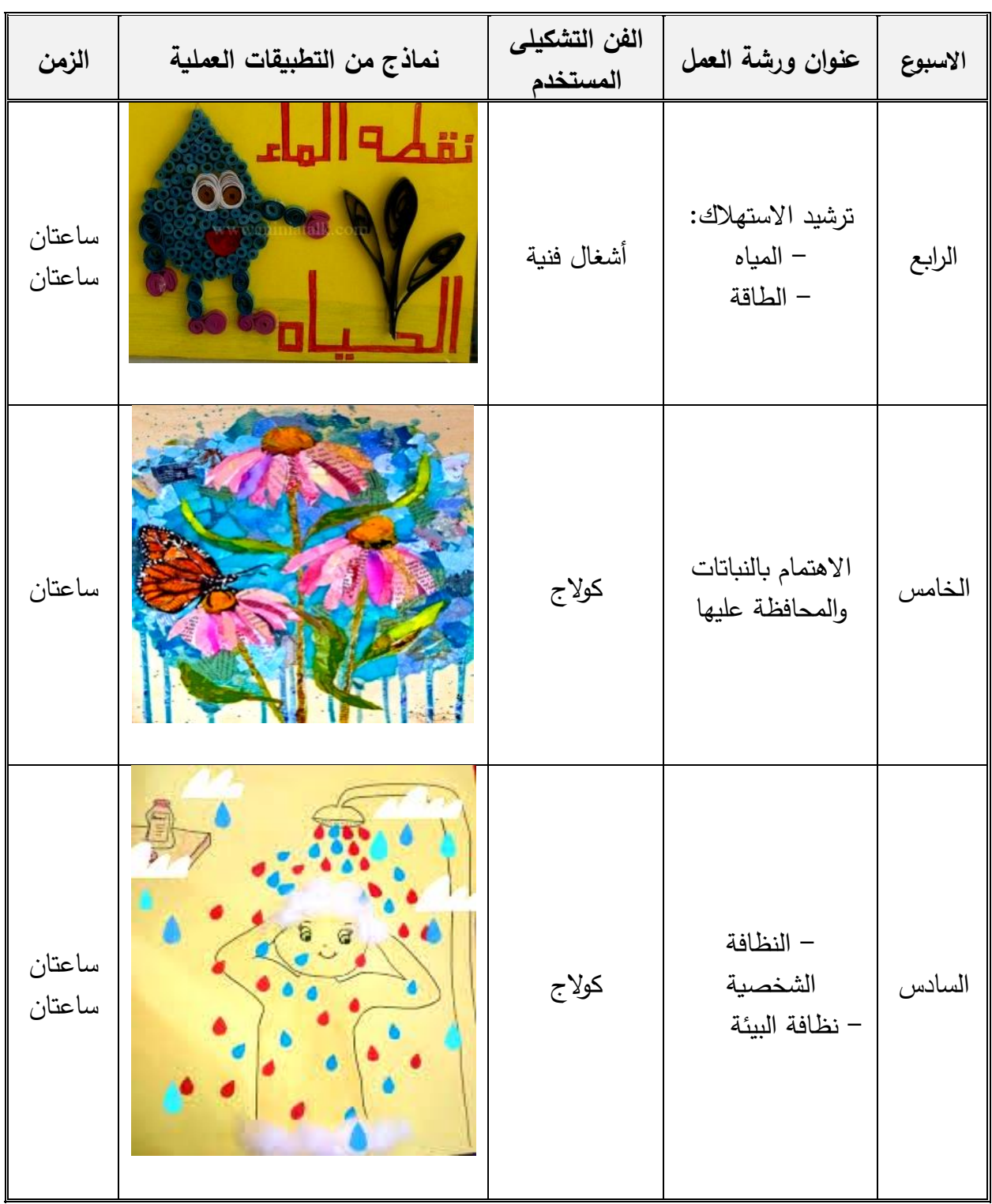

130

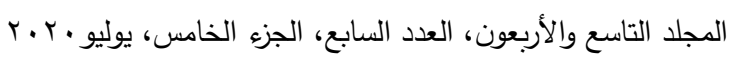

الترقيم الدولي 0826- ISSN 1110 
مجلة العلوم البيئية

معهد الدراسات والبحوث البيئية - جامعة عين شمس

نهلة صلاح علي وآخرون

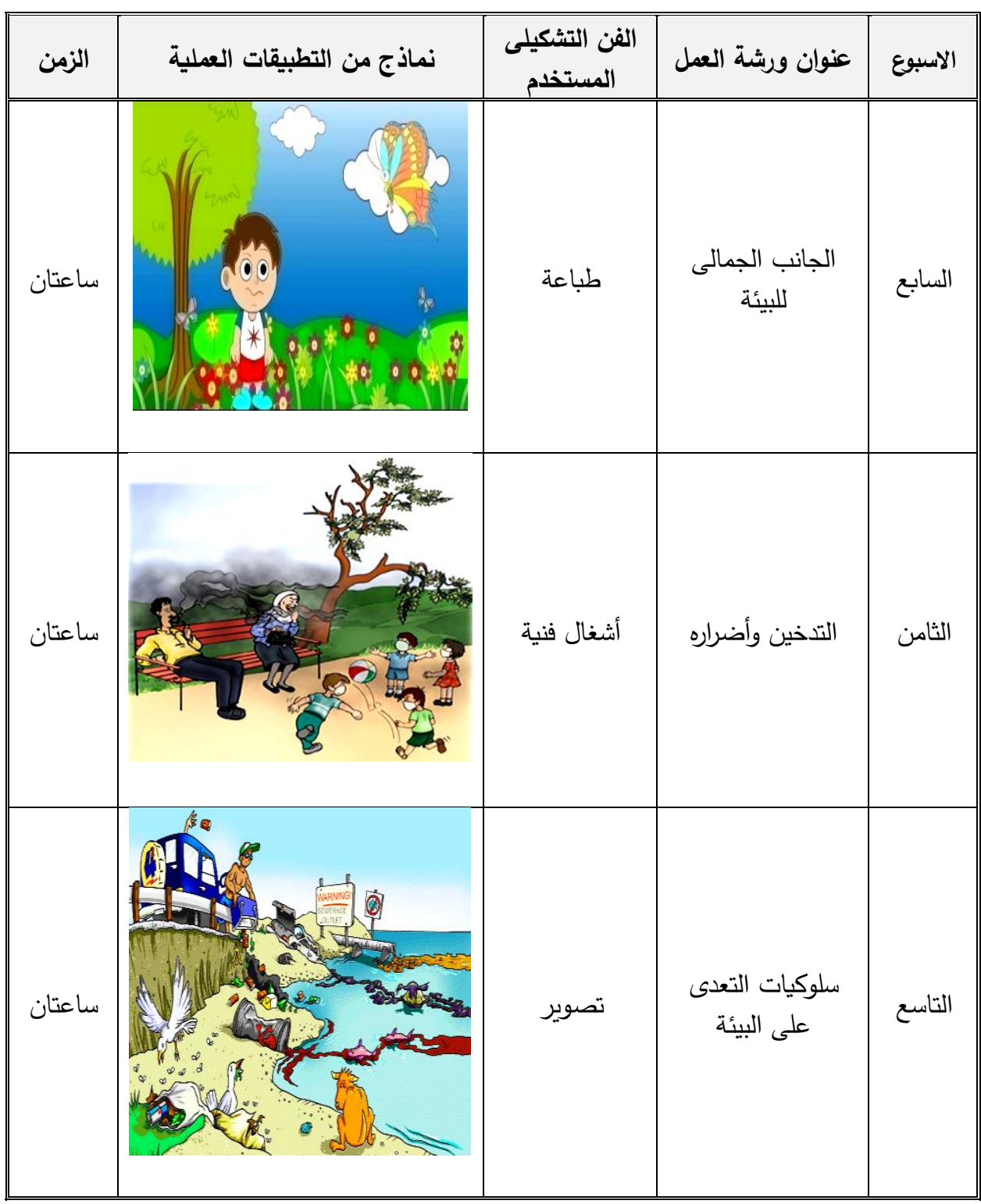

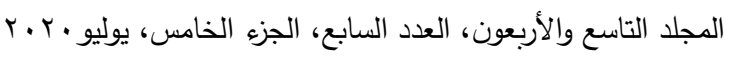

الترقيم الدولي 0826- ISSN 1110 


\section{|}

فيما يلى وصفاً تفصيلياً لنتائج البحث الاحصائية ومناقشتها فى ضوه الإطار النظرى

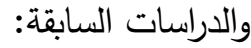
نتائج الفرض الأول: "توجد فروق ذات دلالة إحصائية بين متوسطات درجات أطفال الشوراع على أبعاد مقياس السلوك البيئى بعد إستخدام الفن التشكيلى فى القياسين القبلى والبعدى

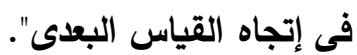
جدول (0): اختبار ت T-Test لحساب الفروق بين متوسطات درجات أطفال الثوراع على

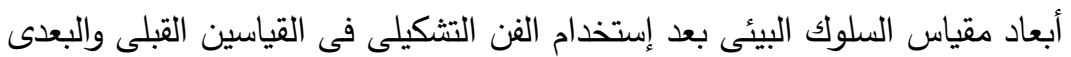

\begin{tabular}{|c|c|c|c|c|c|c|c|}
\hline \multirow{2}{*}{ التأثير } & \multirow{2}{*}{ معنوى معندية } & \multirow{2}{*}{ قيمة (ت) } & \multicolumn{2}{|c|}{ 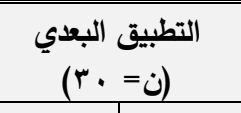 } & \multicolumn{2}{|c|}{ 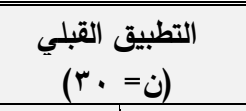 } & \multirow[t]{2}{*}{ المتغيرات } \\
\hline & & & الانحراف & المتوسط & الانحراف & المتوسط & \\
\hline$\cdot, 91$ & دالة ل & $18, \cdot 9$ & $Y, Y_{T}$ & $19,1 \mathrm{~V}$ & $Y, V T$ & $\Lambda, \cdot r$ & التلوث بأنواعه \\
\hline$\cdot, \wedge 7$ & 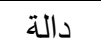 & Ir,Arq & $\cdot, 9 \leq$ & $\varepsilon, \wedge \vee$ & $\cdot, 99$ & $1,7 V$ & تدوير المخلفات \\
\hline$\cdot, \mathrm{\vee} \wedge$ & 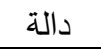 & $9, \varepsilon \cdot 9$ & $\cdot, \wedge 7$ & $\varepsilon, 7$. & $1, r$ & $r, \cdot V$ & ترشيد استهلاك المياه \\
\hline$\cdot, 79$ & دالة & $V, r \cdot V$ & $\cdot, V Y$ & r, & $1, \cdot r$ & $1, V$ & ترشيد استهلاك الطاقة \\
\hline$\cdot, \lambda r$ & دالة الة & $1 \cdot, V \leqslant r$ & $\cdot, 97$ & $\varepsilon, 7$ & 1,00 & ו, 1, & الإهتمام بالنباتات \\
\hline$\cdot, 7$ & 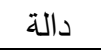 & $V, 1 \wedge 7$ & 1,1, & 7,11 & 1,00 & $r, \Sigma r$ & النظافة (الشخصية، البيئة) \\
\hline$\cdot, 7$. & دالة الة & $0,74 r$ & $\cdot, \vee \leqslant$ & $r, \ldots$ & 1,14 & 1,7 & الإهتمام بالجانب الجمالى \\
\hline$\cdot, \vee \vee 7$ & 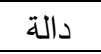 & 1,970 & $1, r \leq$ & L, & $\cdot, 9 r$ & $1, \wedge$. & أضرار التدخين \\
\hline$\cdot, \wedge 7$ & 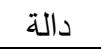 & $1 Y, 997$ & $r, \wedge \wedge$ & Ir,IV & $1, \varepsilon 1$ & $\varepsilon, O V$ & التعدي على البيئة \\
\hline$\cdot, 90$ & 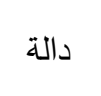 & rr,qrE & $V, \cdot 7$ & $T Y, Y V$ & $\varepsilon, V T$ & $r\urcorner, V$. & إجمالي مقياس السلوك \\
\hline
\end{tabular}

$$
\begin{aligned}
& \text { المجلد التاسع والأربعون، العدد السابع، الجزء الخامس، يوليو • r. } \\
& \text { الترقيم الدولي 0826-110 110 العون، }
\end{aligned}
$$


يتضح من الجدول السابق أنه توجد فروق بين متوسطات درجات القياس (القبلى

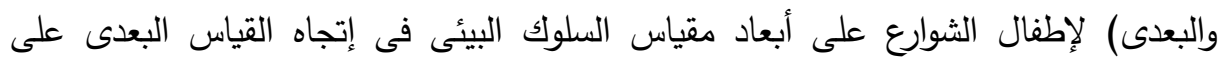

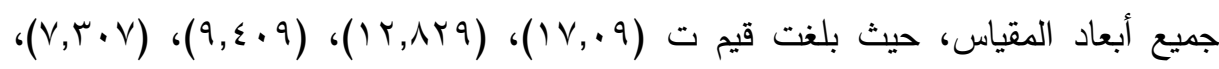
تلى ترتيب الأبعاد وهى جميعها قيم دالة عند مستوى معنوية (0. •. . •) حيث أن الدرجة العالية تعبر

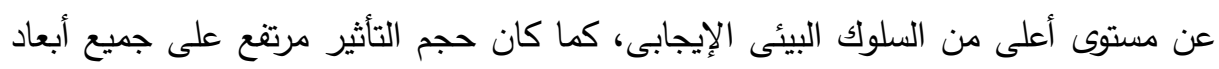
المقياس، مما يعنى تحقق الفرض الأول إحصائياً.

ويرجع ذلك الى التتوع فى مجالات الفن التثكيلى التى إعتمدت عليها الباحثتان مع التعان الاطفال، والتى انبثقت من البيئة بما تحمله من مواد وخامات مثيرة سواء طبيعية أو مصطنعة،

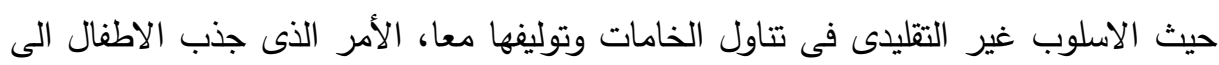

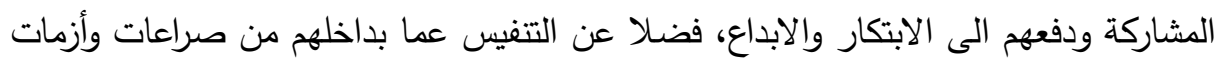

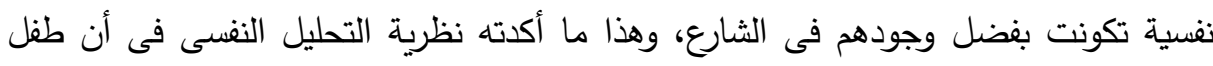
الثارع لديه عدوان كامن فى اللاشعور، وإن توجيه الاهتمام للطفل وإتاحة الفرصة أمامه وهنه

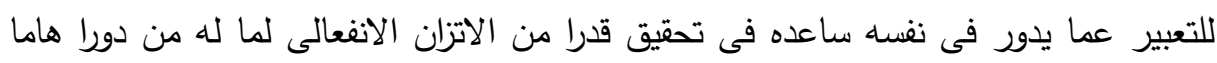

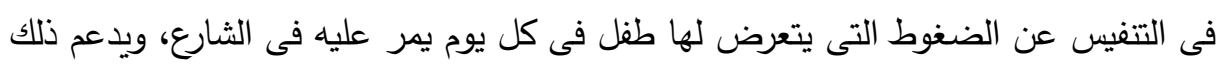

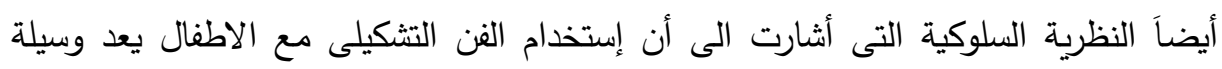

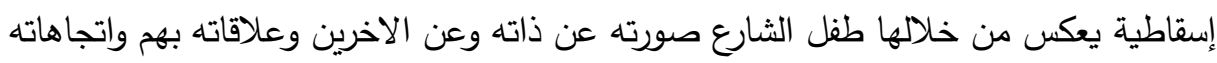

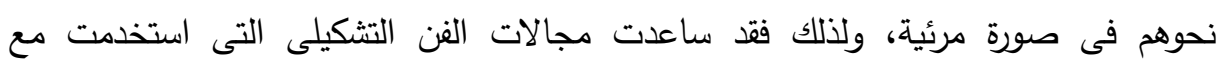
الاطفال فى إكسابهم العديد من المعارف والمهارات التى تمثلت فى معرفئة ولى الموارد البيئية

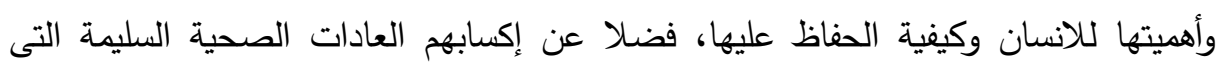

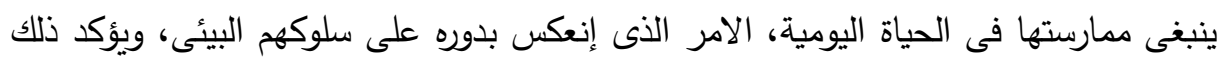

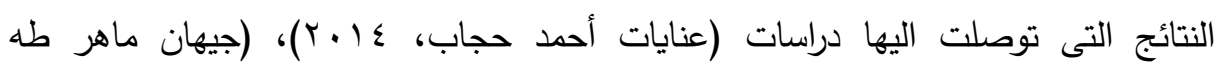

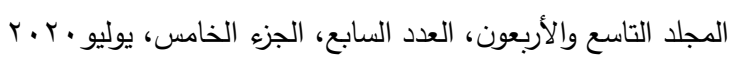

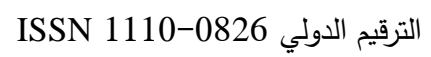




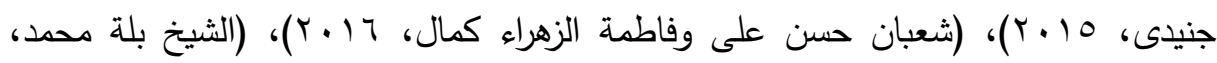

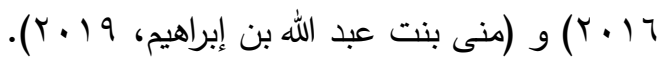
نتائج الفرض الثانى: "لا توجد فروق ذات دلالة إحصائية بين متوسطات درجات أطفال

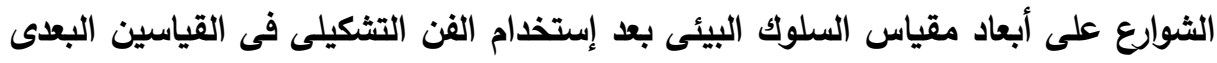
والتتبعى". جدول (†): اختبار ت T-Test لحساب الفروق بين متوسطات درجات أطفال الثوارع على أبعاد مقياس السلوك البيئى بعد إستخدام الفن التشكيلى فى القياسين البعدى ملوسي

\begin{tabular}{|c|c|c|c|c|c|c|}
\hline \multirow{2}{*}{ معندئ معندية } & \multirow{2}{*}{ قيمة } & \multicolumn{2}{|c|}{ 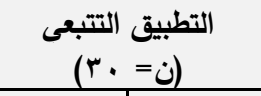 } & \multicolumn{2}{|c|}{ 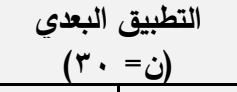 } & \multirow[t]{2}{*}{ المتغيرات } \\
\hline & & الانحراف & المتوسط & الانحراف & المتوسط & \\
\hline غير دالة &., $.0 \wedge$ & $r, 19$ & $19,1 \%$ & $Y, Y Y$ & $19,1 V$ & التلوث بأنواعه \\
\hline غير دالة & $\cdot, 009$ & $\cdot, 91$ & $0, \ldots$ &., $9 \leq$ & $\varepsilon, \wedge \vee$ & تدوبر المخلفات \\
\hline غير دالة & $\cdot, r \mu \wedge$ & $\cdot, 74$ & $\varepsilon, 7 V$ & $\cdot, \wedge \uparrow$ & $\varepsilon, 7$. & ترشيد استهلاك المياه \\
\hline غير دالة & $\cdot, 00 \mathrm{r}$ & $\cdot, \uparrow \wedge$ & $r, \leqslant V$ & $\cdot, \mathrm{Vr}$ & $r, r v$ & ترشيداستهلاك الطاقة \\
\hline غير دالة & $\cdot$, YVO & $\cdot, 9 r$ & $\varepsilon, \vee$. & $\cdot, 97$ & $\varepsilon, 7 r$ & الإهتمام بالنباتات والمحافظة عليها \\
\hline غير دالة & $\cdot, 194$ & $1, r_{1}$ & $7, \cdot V$ & $1, r$ & 7,14 & النظافة (الثخصية، البيئة) \\
\hline غير دالة & $\cdot, 001$ & $\cdot, 74$ & $r, 1$. & $\cdot, \mathrm{V} \leq$ & $r, \ldots$ & الإهتمام بالجانب الجمالى للبيئة \\
\hline غير دالة & . & $1,1 \mathrm{~V}$ & $\varepsilon, \leqslant$ & $1, r \leq$ & $\varepsilon, r r$ & أضرار التخخين \\
\hline غير دالة &., .91 & $r, \wedge$. & Ir,Yr & $r, \wedge \wedge$ & $I r, 1 V$ & التعدي على البيئة \\
\hline غير دالة & $\cdot, r \cdot v$ & $\Lambda, \leqslant 9$ & $\wedge \neg, \wedge r$ & $9,1 \leq$ & $\Lambda 7,1 \mu$ & إجمالي مقياس السلوك البيئي \\
\hline
\end{tabular}

يتضح من الجدول السابق عدم وجود فروق ذات دلالة إحصائية بين متوسط درجات

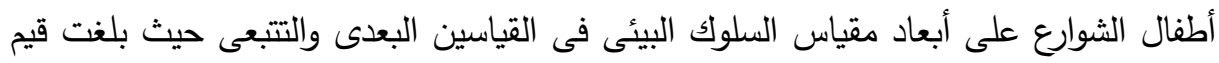


(ت) المحسوبة جميعها قيم أعلى من (ت) الجدولية وهي قيم غير دالة معنوياً عند مستوى معنوية (0. (•))، مما يثبت صحة الفرض الثانى.

ويرجع ذلك الى فاعلية استخدام مجالات الفن التشكيلى في تعديل بعض أنسات أنماط السلوك

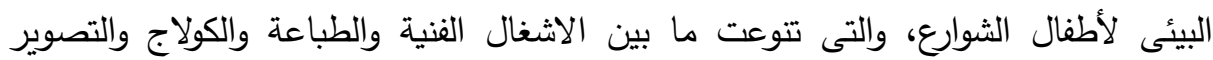

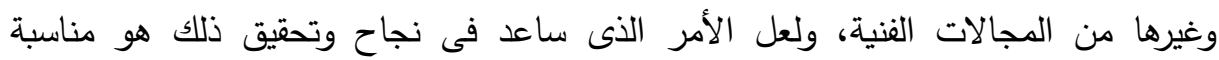

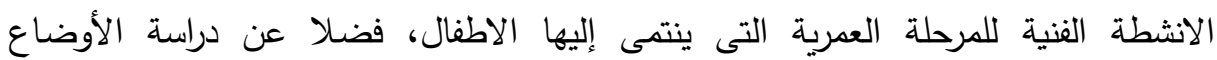

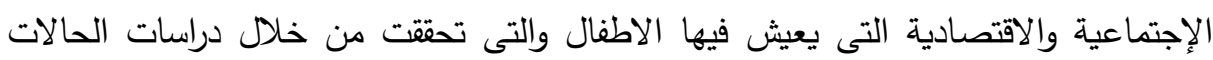
التى قامت بها الباحثتان، والتى من خلالها تم وضع تصور كامل لطبيعة الاطفال وخصائصهم ومدى إحتياجاتهم، لتحديد أنسب المجالات الفنية التى يمكن التدخل من خلانلانها

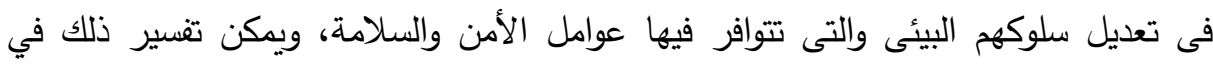

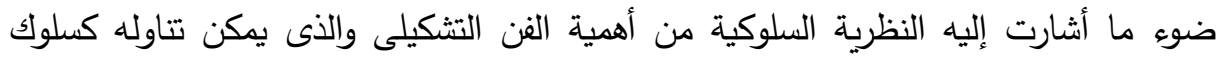
يمكن تعليمه وإكسابه للأطفال، وذلك من خلال تتظيم الظروف البيئية اللازمة باعتبار أن البيئة هى المسئولة عن تثكيل السلوك وتدعيمه. وإضافة الى ما سبق، فإن تتوع الأساليب والفنيات التى استخدمتها الباحثتان فى تعديل السلوك والتى كان من أهمها التعزيز بأنواعه والنمذجة والتعميم والتركيز على تدعيم السلوكيات

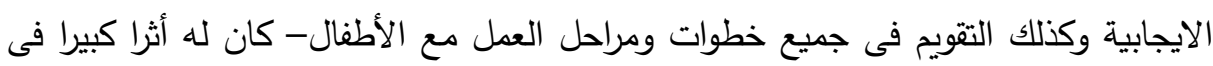

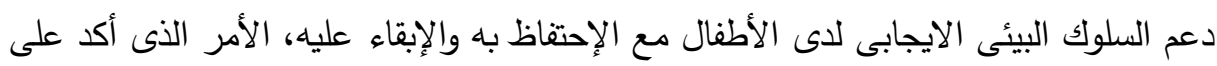

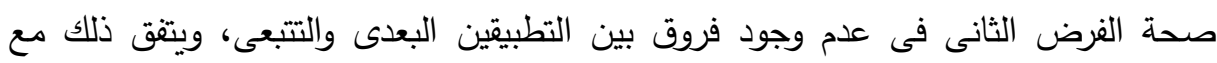

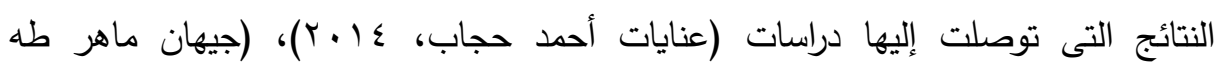

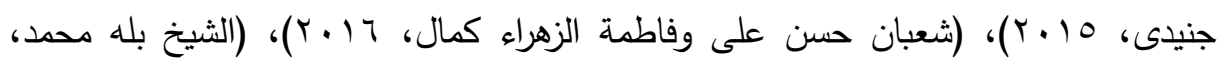

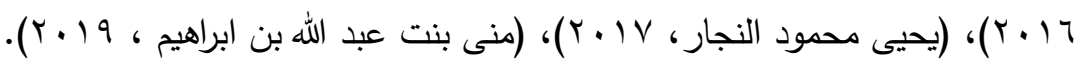

$$
\begin{aligned}
& \text { المجلد التاسع والأربعون، العدد السابع، الجزء الخامس، يوليو . r. }
\end{aligned}
$$

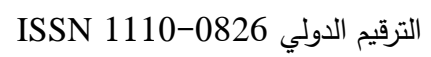




$$
\begin{aligned}
& \text { مجلة العلوم البيئية } \\
& \text { معهد الدراسات والبحوث البيئية - جامعة عين شمس لكس } \\
& \text { نهلة صلاح علي وآخرون }
\end{aligned}
$$

نتائج الفرض الثالث: "توجد فروق ذات دلالة إحصائية بين متوسطات درجات الذكور والإناث على أبعاد مقياس السلوك البيئى".

\begin{tabular}{|c|c|c|c|c|c|c|}
\hline \multirow{2}{*}{ 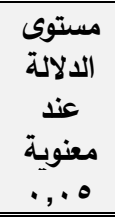 } & \multirow{2}{*}{ ق) قيمة } & \multicolumn{2}{|c|}{ إناث (ن= Y Y Y } & \multicolumn{2}{|c|}{ ذكور (ن= 1 1 ) } & \multirow{2}{*}{ المتغيرات } \\
\hline & & المعياري & المتوسط & المعياري & المتوسط & \\
\hline دالة ل & $1,11 \pi$ & $\cdot$, Vo & r, ro & $\cdot, V T$ & $r, q \leq$ & التلوث بأنواعه \\
\hline غير دالة &., 107 & $\cdot, 9 \leq$ & $\varepsilon, \Lambda \Gamma$ & $\cdot, 97$ & $\varepsilon, \wedge 9$ & تدوير المخلفات \\
\hline غير دالة & $1, \times 1$. & $\cdot$, TV & $\varepsilon, 94$ & $\cdot, 9 r$ & $\varepsilon, \Gamma q$ & ترشيد استهلاك المياه \\
\hline دالة & $r, 7,7$ & $\cdot, \leqslant 0$ & r,vo & $\cdot, \vee \vee 4$ & $r, 11$ & ترشيداستهلالك الطاقة \\
\hline دالة & $r, 99 \wedge$ & $\cdot, 70$ & $0, \pi$ & $\cdot, \wedge 7$ & $\varepsilon, 1 V$ & الإهتمام بالنباتات والمحافظة عليها \\
\hline دالة & $\varepsilon, r 10$ & $\cdot, V Y$ & $V, I V$ & $1, r$. & $0, \varepsilon \leqslant$ & النظافة (الشخصية، البيئة) \\
\hline دالة & $\varepsilon, 00 Y$ & $\cdot$, TV & $r, 0 \Lambda$ & $\cdot, 0$. & $r, 71$ & الإهتمام بالجانب الجمالى للبيئة \\
\hline دالة & $7,7)$. & • TV & $0,0$. & ד & $r, 07$ & أضرار التتخين \\
\hline دالة & $7,9.1$ & $1, \cdot 1$ & $1 \varepsilon, 9 r$ & $r, 11$ & سז, 1 & التعدي على البيئة \\
\hline دالة & $\checkmark, 19 r$ & $\varepsilon, \ldots$ & $90, \ldots$ & $7, r$. & $\Lambda \cdot, r Y$ & إجمالى مقياس السلوك البيئ \\
\hline
\end{tabular}
جدول (V): اختبار ت T-Test لحساب الفروق بين متوسطات درجات الذكور والاناث على أبعاد مقياس السلوك البيئى

يتضح من الجدول السابق وجود فروق بين متوسطات درجات الذكور والإناث على أبعاد مقياس السلوك البيئى، حيث وجدت فروق ذات دلالة إحصائية بين متوسطات درجات الأطفال

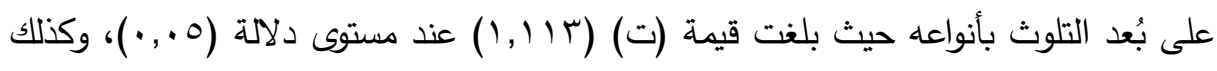

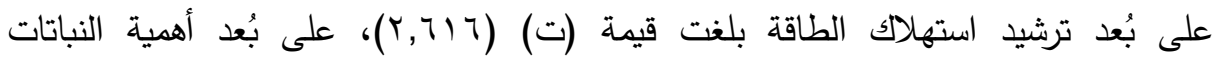

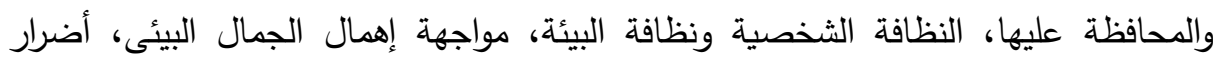

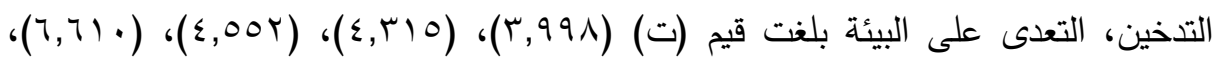

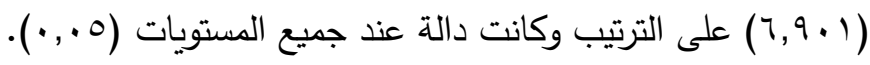


ويتضح من نتيجة هذا الفرض وجود فروق بين الأطفال الذكور والإناث على الدرجة الكلية لمقياس السلوك البيئى، حيث إتضحت الفروق على أبعاد (التلوث بانواعه)، (ترشيد استهلاك الطاقة بالمنازل)، (أهمية النباتات والمحافظة عليها)،(النظافة الثخصية والبيئية)، (مواجهة إهمال الجمال البيئي)، (أضرار التدخين)، (التعدى على البيئة) وقد يرجع ذلك إلى الى الى

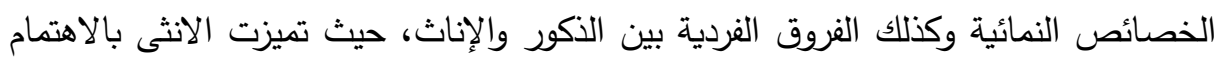

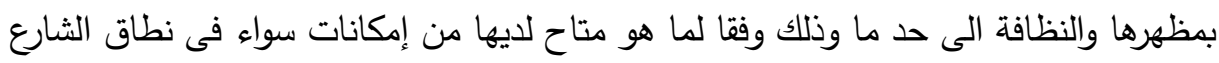

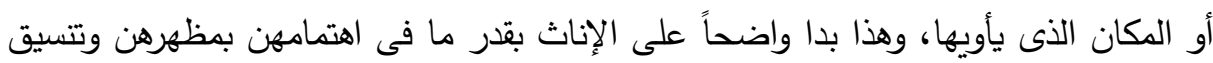
الملابس إلى جانب تعبيرهن عن الاهتمام بزراعة النباتات وتعاطفهم تجاه البيئة، فى حين الإنى

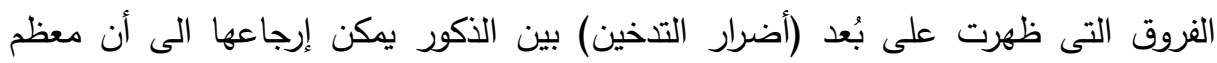

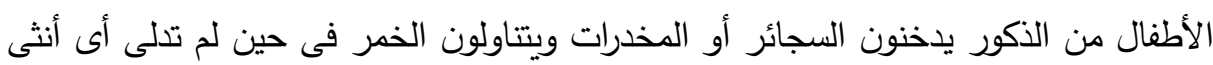

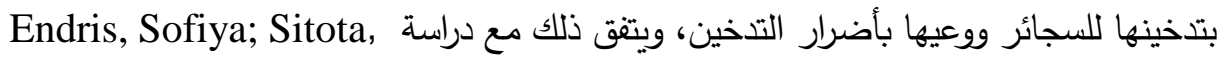
Galata المخدرة والكحولية.

ولعل من الامور التى ساعدت على وجود فروق بين الذكور والإناث على أبعاد مقياس السلوك البيئى هى خبرات الطفولة والقيم والاتجاهات التى إكتسبها الطفل من عملية التنشئة الاجتماعية، فبعض الاطفال كانوا ملتحقين بمدارس ونظرا للظروف الاسرية وشدة الاحتياج

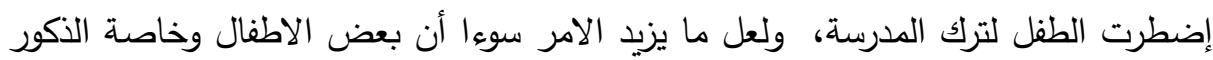
يتجهون للثارع للبحث عن اشباع احتياجاتهم واحتياجات اسرهم وخاصة مع اعداد الاسر

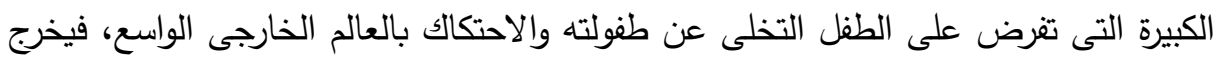

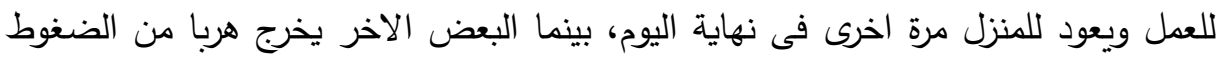

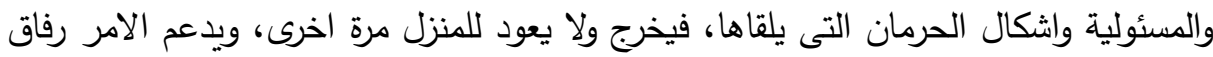
السوء الذين يستقطبونه الى الاعمال المنافية والتسول والانحراف بجانب التدخين او ادمان

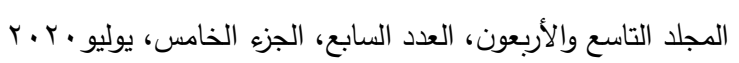

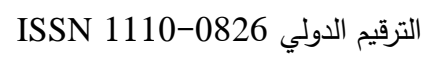




$$
\begin{aligned}
& \text { مجلة العلوم البيئية } \\
& \text { معهد الدراسات والبحوث البيئية - جامعة عين شمس لئن } \\
& \text { نهلة صلاح علي وآخرون }
\end{aligned}
$$

الكحوليات او المخدرات، وهذا يتفق مع نظرية التحليل النفسى والتى أشارت الى أن خروج

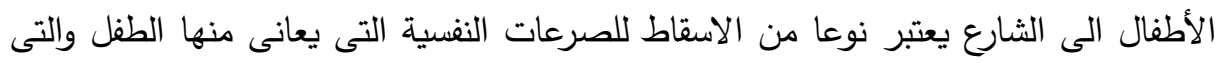
حدثت بفعل سوء المعاملة والحرمان الذى انعكس على إحساس الاطفال بالضياع والنبذ، ويتفق ئقانق

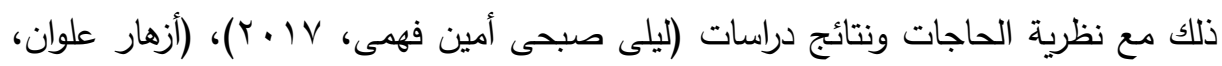
19 19

$$
\cdot(r \cdot 19
$$

الفرض الرابع: "توجد علاقة ارتباطية ذات دلالة احصائية بين المستوى الإجتماعى

\begin{tabular}{|c|c|c|}
\hline \multicolumn{2}{|c|}{ خروج الأطفال إلى الثارع } & \multirow{2}{*}{ أبعاد الاستمارة } \\
\hline مستوى الدلالة & معامل الإرتباط & \\
\hline 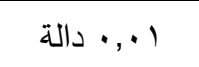 & $\left({ }^{* *}\right) \cdot, Y Y I$ & نقص توافر الاحتياجات اليومية \\
\hline r •, •• دالة & $(*) ., r q \leq$ & نوع النقائص فى توفير احتياجاتك \\
\hline 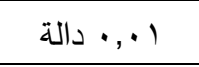 & $(* *) \cdot, \varepsilon r r-$ & عمل الطفل \\
\hline 帛 & $\left(^{*}\right) ., r \leqslant r$ & مع من يعيش الطفل \\
\hline ع •., • دالة & $\left({ }^{(*)}\right), Y \wedge \vee$ & من الذي يعول الأسرة \\
\hline
\end{tabular}
الإقتصادى للأسرة وخروج الأطفال إلى الثارع". جدول (^): العلاقة الارتباطية بين المستوى الإجتماعى الإقتصادى للأسرة وخروج الأطفال

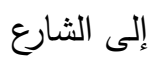

• وجود علاقة ارتباطية ذات دلالة إحصائية بين نقص توافر الإحتياجات وخروج الأطفال

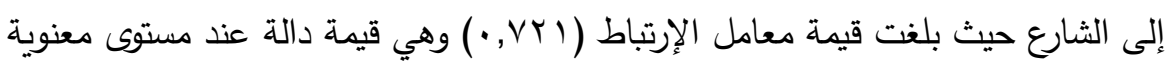
$\cdot(\cdot, \cdot 1)$ 
• وجود علاقة ارتباطية ذات دلالة إحصائية بين نوع النقائص فى توفير احتياجات الأطفال

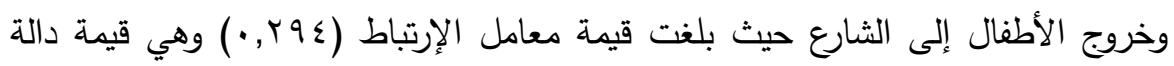

$$
\text { عند مستوى معنوية (r •., (·). }
$$

وجود علاقة ارتباطية ذات دلالة احصائية بين عمل الطفل وخروج الأطفال إلى الثارع

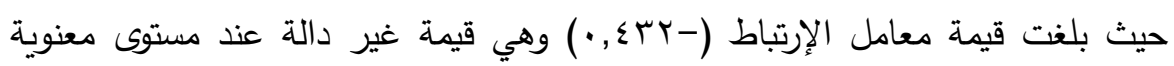

$$
\cdot(\cdot, \cdot 1)
$$

• وجود علاقة ارتباطية ذات دلالة احصائية بين من يعيش معهم الطفل وهروبه إلى الثارع

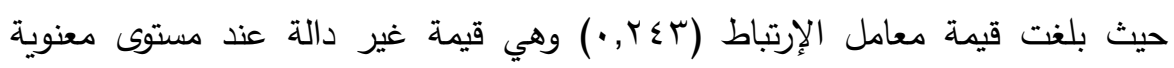

$$
\cdot(\cdot, \cdot r)
$$

• وجود علاقة ارتباطية ذات دلالة احصائية بين عائل الأسرة وخروج الطفل إلى الثارع

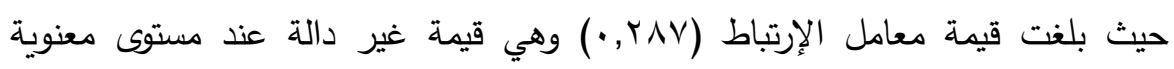

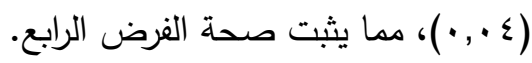

ويرجع ذلك الى أن جميع أطفال الثوراع -عينة البحث- ينحدرون من مناطق عشوائية

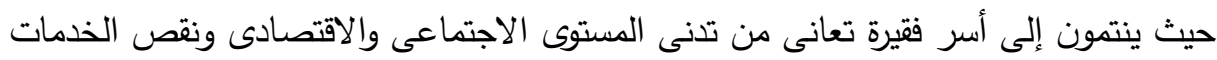

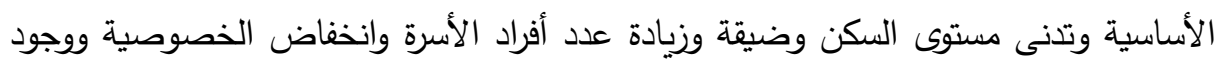

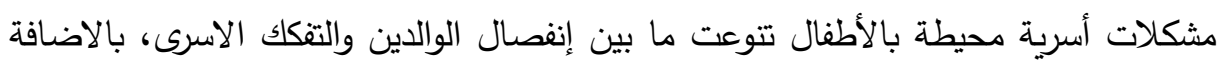

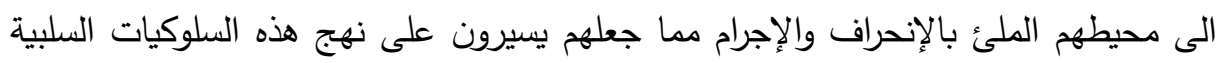
وانتشار الأمراض وممارسة الأعمال غير المشروعة.

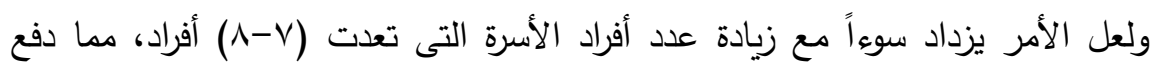

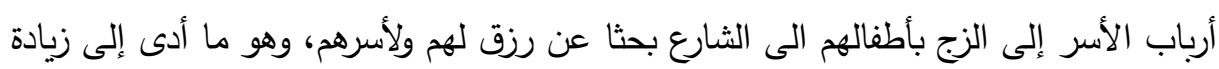

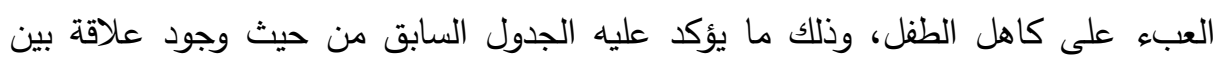
(خروج الأطفال إلى الثارع )، و (نقص توفير احتياجات الأطفال اليومية) ، ويدعم ذلك نظرية

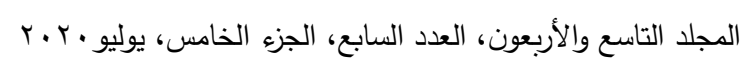

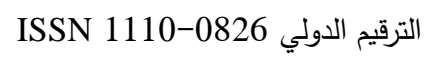




$$
\begin{aligned}
& \text { مجلة العلوم البيئية } \\
& \text { معهد الدراسات والبحوث البيئية - جامعة عين شمس لباس } \\
& \text { نهلة صلاح علي وآخرون }
\end{aligned}
$$

الحاجات التى اشارت الى خروج الطفل الى الثارع يكون وراءه دوافع قوية لاشباع الحاجات،

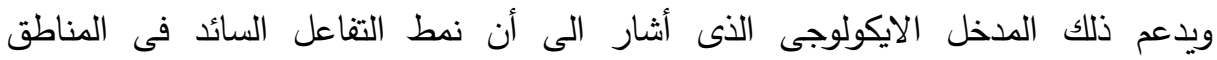

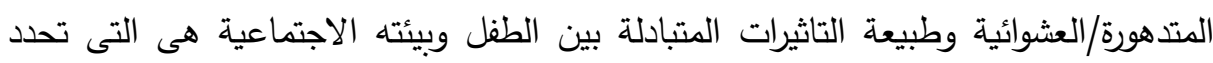
وتوجه سلوكه البيئى.

أما بالنسبة للعلاقة بين (خروج الأطفال للشارع)، (عمل الطفل) فيؤكد فكرة دفع الآباء

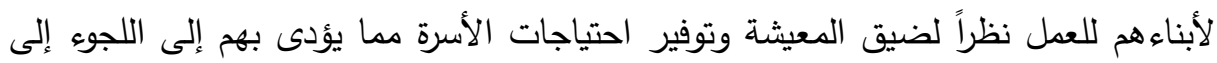
الثارع والعمل في بعض الأعمال الهامشية وغير المشروعة (كالتسول وغيرها) وقد يلجأ

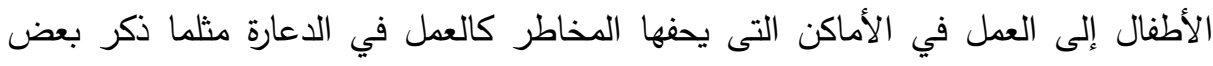

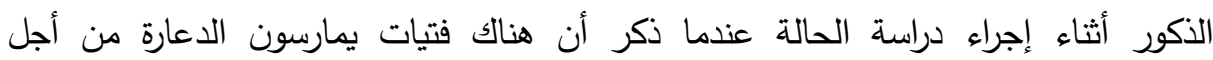
الحصول على أموال ويعتبرون ذلك مهنتهم، وهنالك أيضاً من يدفع بزوجاته للعمل في الدعارة

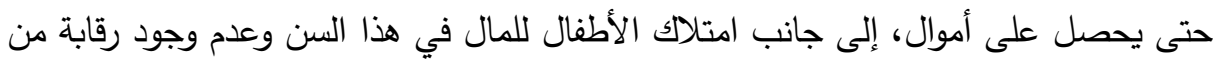

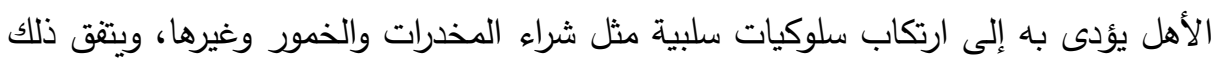

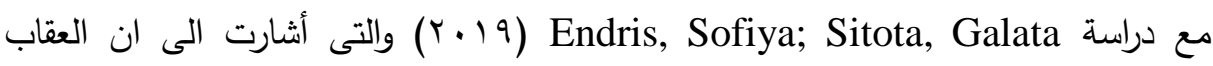
الوالدى المسىء والفقر والكراهية من الأباء وسلوك الوالدين المدمنين للكحوليات كلها عوامل تدفع الاطفال لتعاطى المواد المخدرة ، فالطفل يتأثر بالنماذج السلوكية التى يتعرض لهاء لها.

\section{توكيليه اللهمث}

هى ضوء النتائج التى توصل اليها البحث الحالى ترى الباحثتان ضرورة توفير نظام إجتماعى يهتم بتفعيل آلية لرصد أطفال الثوارع المعرضين للخطر وضبطهم. تفعيل دور مؤسسات المجتمع للتدخل المبكر وتوفير البرامج الخدمية والارشادية والتدريبية والتاهيلية لحماية الأطفال وأسرهم من أنواع العنف والإستغلال.

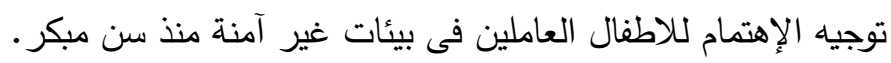

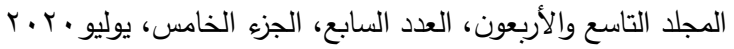

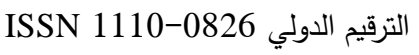




$$
\begin{aligned}
& \text { مجلة العلوم البيئية } \\
& \text { معهد الدراسات والبحوث البيئية - جامعة عين شمس به } \\
& \text { نهلة صلاح علي وآخرون }
\end{aligned}
$$

العمل على تطوير برامج مكافحة الفقر ودعم التعاون المتبادل بين الهيئات العامة

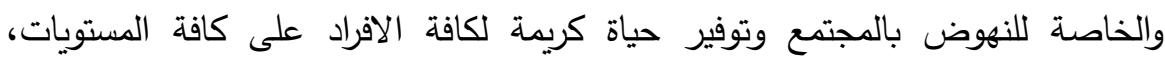
ومحاولة دمج أطفال الثوارع فى المجتمع الاكبر وتقديم أوجه الرعاية المختلفة لهم وتحويلهم لطاقة إيجابية تيد المجتمع لا تضره.

\section{sall}

أزهار علوان (9 ( ب): العنف المدرسى وأثره فى انتشار ظاهرة اطفال الثوارع، المجلة العربية

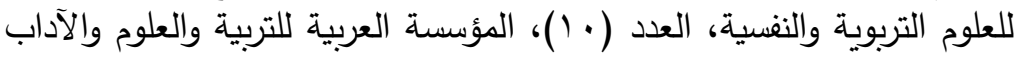

$$
\text { (ALESA) }
$$

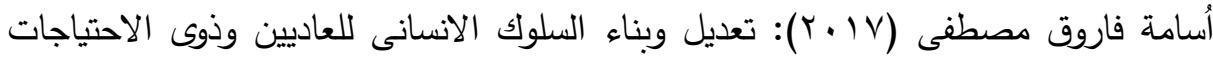
الخاصة، القاهرة: مكتبة الانجلو المصرية.

آمال عبد السميع مليجى باظة (د.ت): إستمارة دراسة الحالة للاطفال، القاهرة: مكتبة الانجلو المصرية.

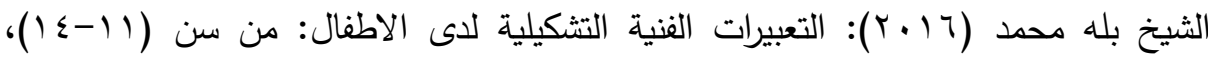
رسالة ماجستير، جامعة ابى بكر بلقايد، الجزائر : تلمسان.

جمال الخطيب (999) (99): تعديل السلوك "القوانين والاجراءات"، الرياض: مكتبة الصفحات الذهبية.

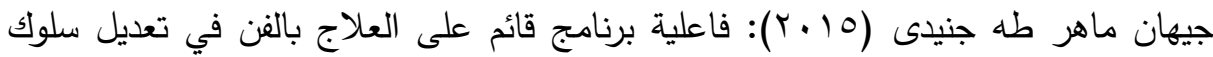

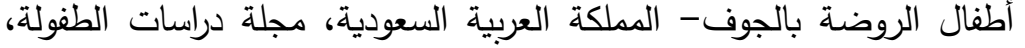

المجلد 1 1 ، العدد VTT، كلية الدراسات العليا للطفولة، جامعة عين شمس.

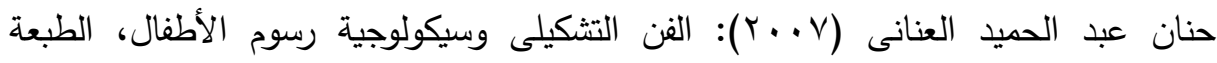

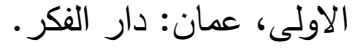

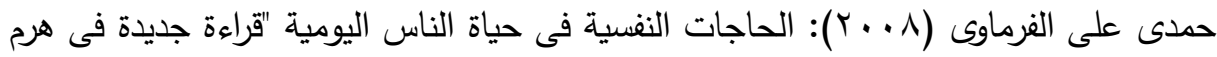
ماسلو"، الطبعة الاولى، القاهرة: دار الفكر العربى.

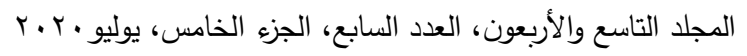

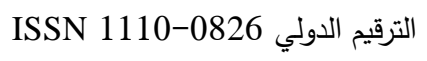


خولة أحمد يحيى (. . . ب): الإضطرابات السلوكية والإنفعالية، عمان : دار الفكر . دينا مصطفى (• • ب): العلاج بالفن، الطبعة الاولى، القاهرة: مكتبة الانجلو المصرية.

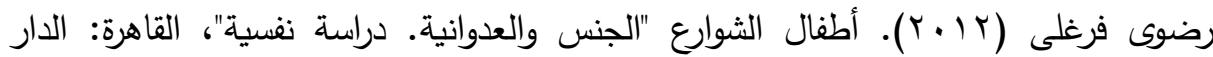

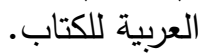

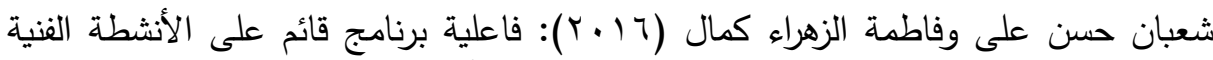

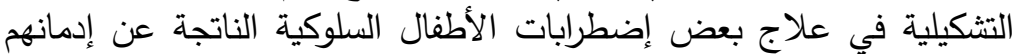

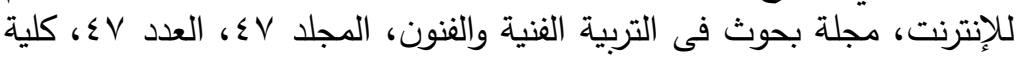
التربية الفنية، جامعة حلوان.

طه عبد العظيم حسين (^^..؟): استراتيجيات تعديل السلوك للعاملين ذوى الإحتياجات الخاصة، الإسكندرية: دار الجامعة الجديدة للنشر.

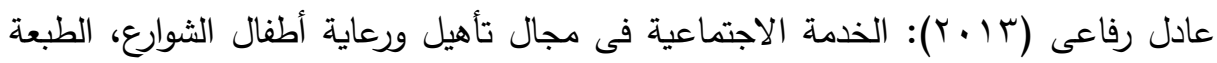

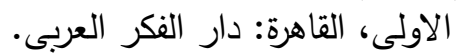

عبد المطلب أمين القريطى ( ( . ب): سيكولوجية ذوى الاحتياجات الخاصة وتربيتهم، الطبعة

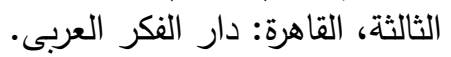

عفاف أحمد محمد فراج ونهى مصطفى محمد عبد العزيز (ع ـ . ب): الفن وذوى الاحتياجات الخاصة، القاهرة: مكتبة الانجلو المصرية.

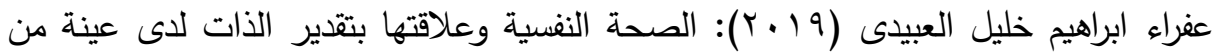

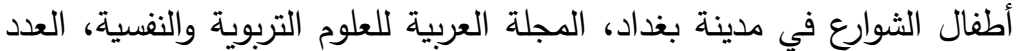

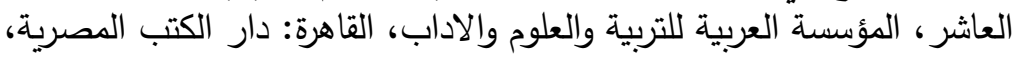

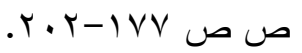

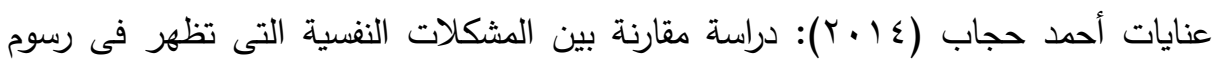

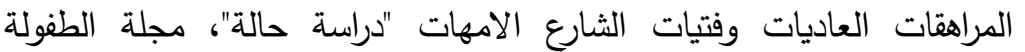

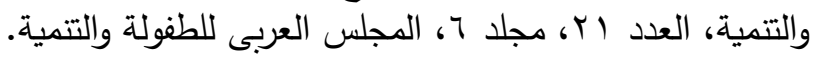

عوض مبارك اليامى (^ . . r): العلاج بالفن التثكيلي، النشر العلمي و المطابع جامعة الملك

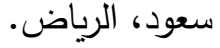

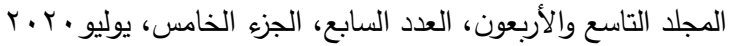

$$
\begin{aligned}
& \text { الترقيم الدولي 0826-110 110 }
\end{aligned}
$$




$$
\begin{aligned}
& \text { مجلة العلوم البيئية } \\
& \text { معهد الدراسات والبحوث البيئية - جامعة عين شمس به } \\
& \text { نهلة صلاح علي وآخرون }
\end{aligned}
$$

فوزية محمود النجاحى وإكرام حمودة الجندى (10 • ب): الابعاد الاجتماعية لظاهرة تشرد

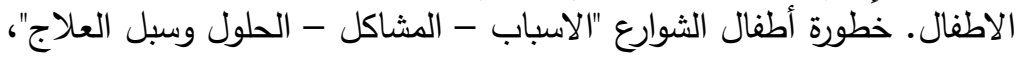

$$
\text { القاهرة: دار الكتاب الحديث. }
$$

كاترين جيلدرد ودافيد جيلدرو (0. ㄷ): الإرشاد النفسى للأطفال "منظور تطبيقى"، ترجمة سميرة أبو الحسن، القاهرة: المجلس الأعلى للثقافة.

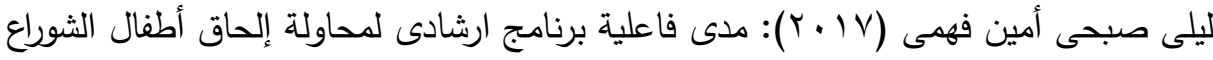

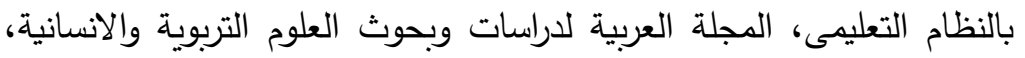

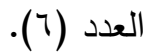

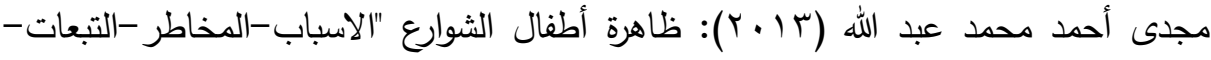
العلاج والوقاية" دراسة فى سيكولوجية الظاهرة، الاسكندرية: دار الطعار المعرفة

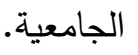

مصطفى عبيد (9901): التربية الفنية لاطفال الحضانة، الاسكندرية: المكتبة العلمية للنشر والتوزيع.

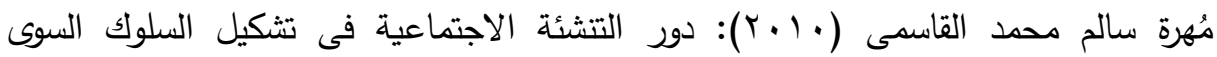
للأبناء، الطبعة الاولى، القاهرة: دار الفكر العربى.

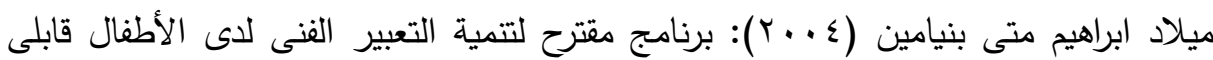
التعلم بالاستفادة من الفنون الحديثة، رسالة دكتوراه، كلية التربية النوعية، التئية جامعة عين شمس.

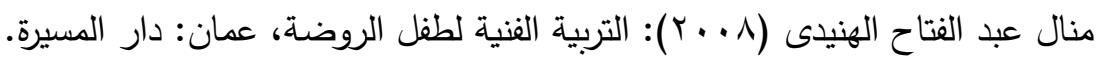
منى بنت عبد الله بن إبراهيم الحميضى (9 ( • ب): برنامج إثرائى مقترح لتتمية مهارات التعبير

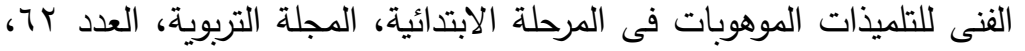

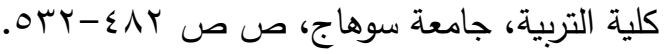

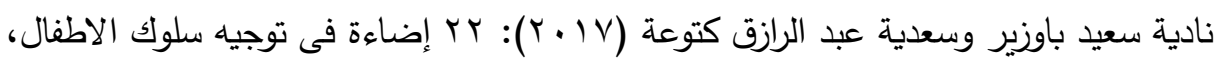
القاهرة: دار الفكر العربى.

$$
\begin{aligned}
& \text { F. r. . المجلد التاسع والأربعون، العدد السابع، الجزء الخامس، يوليو } \\
& \text { الترقيم الدولي 0826- ISSN 1110 }
\end{aligned}
$$




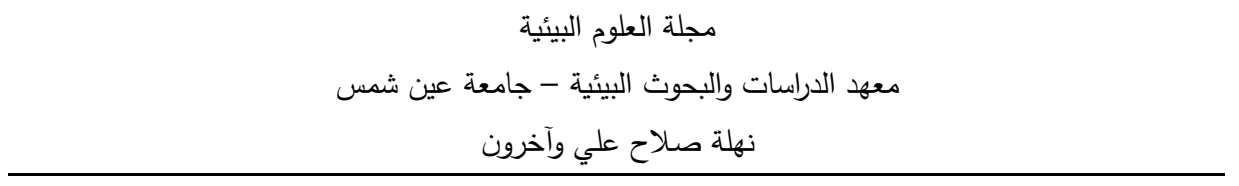

نبيهة السيد عبد العظيم نايل (q . . ץ): صحة البيئة والطفل، الطبعة الاولى، القاهرة: عالم الكتب.

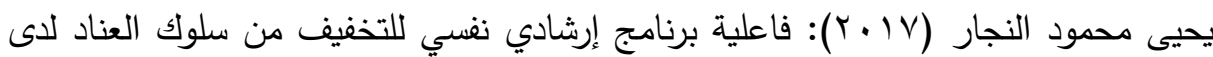

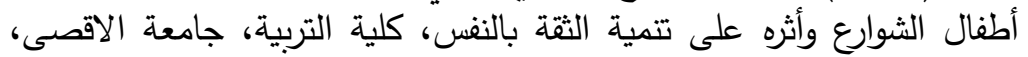
فلسطين.

Adeganha, C. (2002): Street children in Brazil: Causes of the street children phenomenon and causes of the violence against them. (MA) Duquesne University Vol. (41), No. (1), PP. $102-122$.

Endris, Sofiya and Sitota, Galata (2019): Causes and Consequences of Streetism among Street Children in Harar City, Ethiopia, International Journal of Education and Literacy Studies, Vol. (7) Issue (2), PP. 94-99.

Kinyua, Joyce Njeri (2013): Challenges faced by grandparents in managing emotional and behavior problems of orphans in the era of hiv/aids, International Journal of Arts and Entrepreneurship Vol.1, Issue 3, 329-339.

Negra, Christine; Manning, Robert E. (1997): Incorporating Environmental Behavior, Ethics, and Values into Nonformal Environmental Education Programs, The Journal of Environmental Education, vol. 28, No. 2, PP. 1021.

Teal, R. (2004): Street children in urban Nepel: Boys lives on street and shelters. (MA) California State University, Longbeach.

UNICEF Executive Board (1986): Exploition of Working Children and street children, UNICEF Executive Board session, New York.

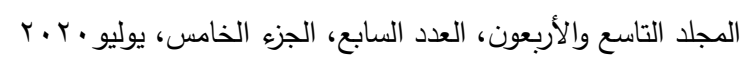

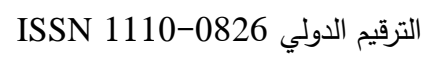




$$
\begin{aligned}
& \text { مجلة العلوم البيئية } \\
& \text { معهد الدراسات والبحوث البيئية - جامعة عين شمس } \\
& \text { نهلة صلاح علي وآخرون }
\end{aligned}
$$

World Health Organization (1993): Programme on Substance Abuse, A One-way street: report on phase 1 of the Street Children Project.

\title{
ENVIRONMENTAL BEHAVIOR MODIFICATION FOR A SAMPLE OF STREETS CHILDREN \\ USING THE PLASTIC ART
}

\section{CASE STUDY}

\author{
Nahla S. Ali ${ }^{(1)}$ and Al-Shaimaa B. Amer ${ }^{(1)}$
}

1) Institute of Environmental Studies \& Research, Ain Shams University

\begin{abstract}
The aim of the current research is try to modify the environmental behavior for a sample of streets children using the plastic art. The research sample consisted of (30) boys and girls from the streets children by (18) males and (12) females whose ages ranged between (9ir) years, the research tools included a case study form, an environmental behavior scale for streets children, and socio-economic level questionnaire (preparation of the two researches).

The results of the research found that there are statistically significant differences between the mean scores for streets children on the dimensions of the environmental behavior scale after using the plastic art in the pre and post measurements in the direction of the dimensional measurement, it was also clear that there were no statistically significant differences between the mean scores of streets

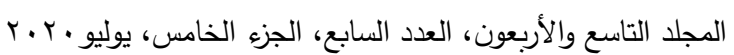

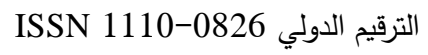




$$
\begin{aligned}
& \text { مجلة العلوم البيئية } \\
& \text { معهد الدراسات والبحوث البيئية - جامعة عين شمس } \\
& \text { نهلة صلاح علي وآخرون }
\end{aligned}
$$

children on the dimensions of the environmental behavior scale after using the plastic art in the dimensional and sequential measurements. There were also statistically significant differences between the mean scores of males and females on the dimensions of the environmental behavior scale in the direction of the dimensional measurement, Whereas, there was a statistically significant correlation between the socio-economic level of the family and the children going out into the street.

The research recommended the necessity of providing a social system concerned with activating a mechanism for monitoring and controlling street children at risk, activating the role of community institutions for early intervention, providing various programs to protect children and their families from types of violence and exploitation, and directing attention to children working in insecure environments from an early age, and working to develop programs to combat Poverty and supporting mutual cooperation between public and private bodies to advance society and provide a decent life for all individuals at all levels, and to try to integrate streets children into the larger society and provide different aspects of care for them and transfer them to positive energy benefiting the community that does not harm it.

Key words: Environmental Behavior Modification, Streets children, Plastit Art, Case Study.

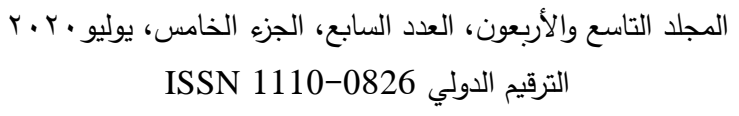

